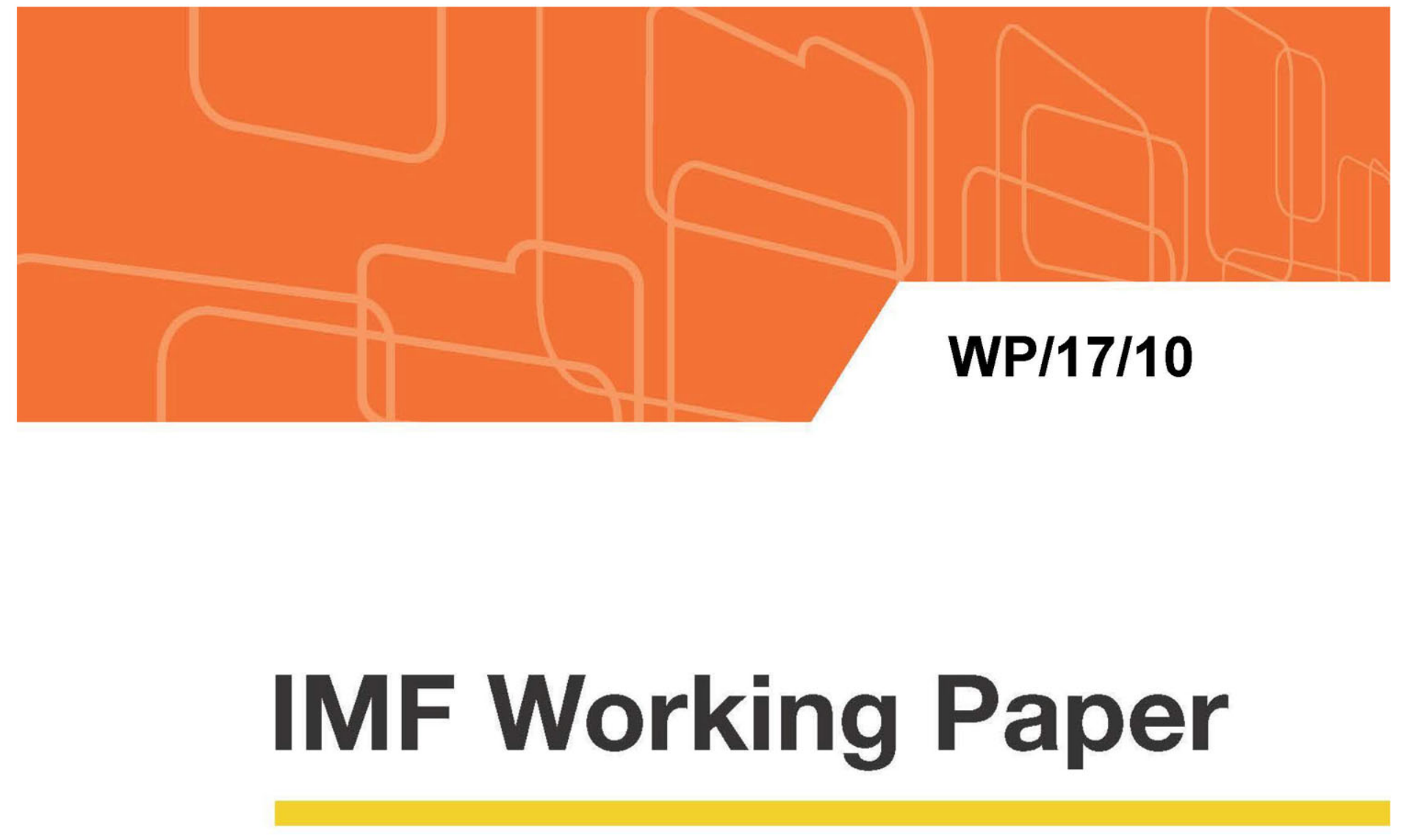

\title{
Collect More, Spend Better: Public Investment in Asian Frontier Markets
}

By Manuk Ghazanchyan, Ricardo Marto, Jiri Jonas, and Kaitlyn Douglass

IMF Working Papers describe research in progress by the authors and are published to elicit comments and to encourage debate. The views expressed in IMF Working Papers are those of the authors and do not necessarily represent the views of the IMF, its Executive Board, or IMF management. 


\section{WP/17/10}

\section{IMF Working Paper}

\section{Collect More, Spend Better: Public Investment in Asian Frontier Markets}

By Manuk Ghazanchyan, Ricardo Marto, Jiri Jonas, and Kaitlyn Douglass

IMF Working Papers describe research in progress by the authors and are published to elicit comments and to encourage debate. The views expressed in IMF Working Papers are those of the authors and do not necessarily represent the views of the IMF, its Executive Board, or IMF management.

$$
\text { I N T ER N A T I O N A L M O NETARY FU N D }
$$




\title{
IMF Working Paper
}

Asia and Pacific, Research, and Fiscal Affairs Departments

\section{Collect More, Spend Better: Public Investment in Asian Frontier Markets}

\section{Prepared by Manuk Ghazanchyan, Ricardo Marto, Jiri Jonas, and Kaitlyn Douglass}

* Authorized for distribution by Alexandros Mourmouras, Prakash Loungani, Manal Fouad January 2017

\section{IMF Working Papers describe research in progress by the author(s) and are published to} elicit comments and to encourage debate. The views expressed in IMF Working Papers are those of the author(s) and do not necessarily represent the views of the IMF, its Executive Board, IMF management, or U.K. DFID.

\begin{abstract}
We use a dynamic small open economy model to explore the macroeconomic impact of alternative public investment scaling-up scenarios, analyzing how improving the efficiency of capital spending and of tax revenue collection affect growth and debt sustainability for three fast-growing Southeast Asian economies: Cambodia, Sri Lanka, and Vietnam. We show that a gradual public investment profile is more favorable than front-loading capital spending because we assume governments are able to gradually learn how to invest more efficiently, accelerating public capital accumulation and therefore growth. We discuss the pros and cons of alternative financing options and identify the financing mix that generates the best macroeconomic outcome. Sometimes overlooked, improving the efficiency of revenue collection over time may ease the burden of fiscal adjustment, achieving higher GDP growth with substantially lower debt-to-GDP ratios, and will help policymakers efficiently meet the challenge of addressing large infrastructure gaps while maintaining debt sustainability.
\end{abstract}

JEL Classification Numbers: E22, E62, F34, H20, H54, H63, O23.

Keywords: Public Investment, Growth, Debt Sustainability, Fiscal Policy, Revenue Collection, Cambodia, Sri Lanka, Vietnam.

Authors’ E-Mail Addresses: MGhazanchayan@imf.org, RMarto@imf.org, JJonas@imf.org, and KDouglass@,imf.org

\footnotetext{
* We thank Paul Cashin and Inoue May for organizing the departmental seminar on public investment and growth in the Asia and Pacific Department (APD), where we presented our work. We also thank Felipe Zanna, Alexandros Mourmouras, John Nelmes, Sonali Jain-Chandra, Gerard Almekinders, Geoffrey Bannister, David Gentry, Carlos Gonçalves, Giovanni Melina, Jochen Schmittmann, Chikahisa Sumi, and Yongzheng Yang for very helpful comments. Special thanks to Estelle Liu Xue for help with data on Vietnam, Lusha Zhuang for excellent research assistance, and Ranee Sirihorachai for outstanding administrative support. All errors are our own. This working paper is part of a research project financed by the U.K.'s Department of International Development (DFID) to support macroeconomic research on Low Income Countries. This paper should not be reported as representing the view of the IMF or of DFID. The views expressed in this paper are those of the authors and do not necessarily represent those of the IMF, or of IMF policy, or of DFID.
} 


\section{Contents}

Page

I. Introduction $\quad \underline{4}$

II. Public Investment, Revenue Collection, and their Efficiencies $\underline{6}$

$\begin{array}{lr}\text { III. The Model } & \underline{10}\end{array}$

$\begin{array}{ll}\text { IV. Calibration } & \underline{15}\end{array}$

$\begin{array}{llr}\text { V. Policy Scenarios } & \underline{18}\end{array}$

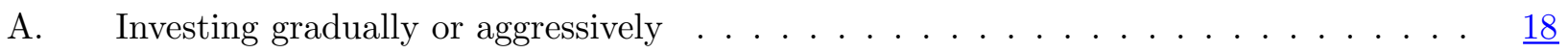

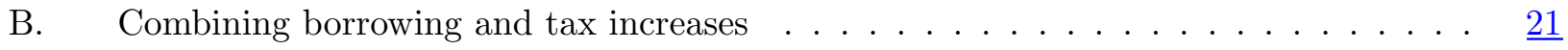

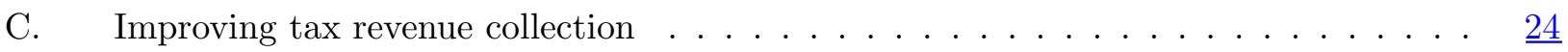

$\begin{array}{ll}\text { VI. Concluding Remarks } & \underline{27}\end{array}$

References $\quad \underline{29}$

$\begin{array}{ll}\text { Appendix } & \underline{31}\end{array}$

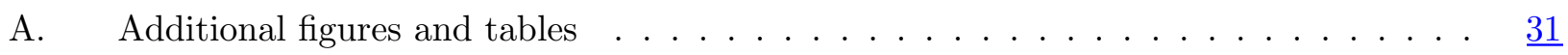

Figures

Figure 1: $\quad$ Strength of public investment management and efficiency . . . . . . . $\underline{8}$

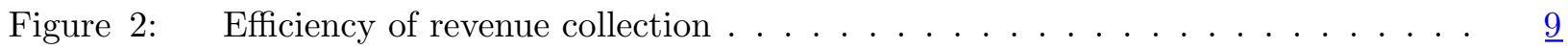

Figure 3: Gradual versus front-loaded investment scaling up . . . . . . . . . . $\underline{19}$

Figure 4: Resorting to debt is an alternative but sustainability risks exist . . . . . $\underline{20}$

Figure 5: Debt financing with tax adjustments is a sensible option . . . . . . . $\underline{23}$

Figure 6: Improving revenue collection reduces debt distress . . . . . . . . . . $\underline{25}$

Figure A.1: Public investment (2011 PPP $\$$-adjusted, \% of GDP) . . . . . . . . . $\underline{31}$

Figure A.2: Private investment (2011 PPP $\$$-adjusted, \% of GDP) . . . . . . . . . $\underline{31}$

Figure A.3: Public capital stock (2011 PPP $\$$-adjusted, \% of GDP) . . . . . . . . $\underline{32}$

Figure A.4: Public investment performance indicators . . . . . . . . . . . . . $\underline{32}$

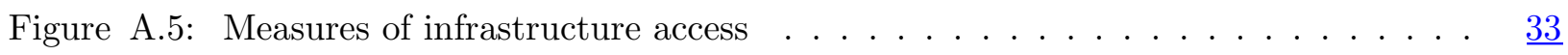

Figure A.6: General government revenues $(\%$ of GDP $) \ldots \ldots \ldots \ldots$

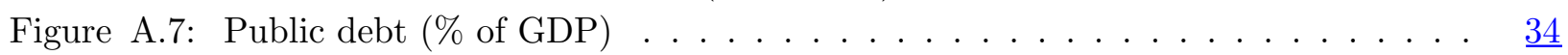

\section{Tables}

Table 1: Selected initial values $(\%) \ldots \ldots \ldots \ldots \ldots \ldots$

Table 2: Impact on growth and public debt after 15 years . . . . . . . . . $\underline{22}$ 
Table 3: $\quad$ Effective tax rates at the end of the investment program (\%) . . . . . $\underline{24}$

Table 4: Revenue collection and impact on growth and public debt after 15 years . . . $\underline{26}$

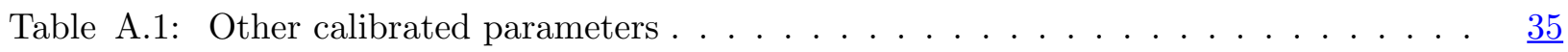




\section{Introduction}

Weak economic performance following the global economic crisis of 2008 brought renewed interest in public investment as a source of both cyclical stimulus and longer-term boost to productivity and growth. For some time, there has been some skepticism about the so-called public-investment-driven growth model, and priority has instead been given to developing private markets and getting incentives right. More recently, a more nuanced view appears to prevail and public investment - in infrastructure, in particular - seems to enjoy improved reputation. Currently low long-term borrowing costs, weak global demand, and substantial infrastructure deficiencies across countries help make the case for a productivity-enhancing increase in public investment (Abiad et al. (2014)).

The proponents of this view argue that increased public investment results in higher productivity gains that are crucial to support robust long-term growth (Spence, 2015), which is in line with the Global Integrated Monetary and Fiscal (GIMF) model simulations (IMF, 2016). By looking at different tools of fiscal stimulus, IMF (2016) finds that public investment has the largest effect on GDP. Rapidly growing countries such as Ethiopia and Bolivia are mentioned as examples of the beneficial impact of sustained increases in public investment on growth (Rodrik, 2016). However, there are also words of caution that higher investment does not automatically lead to higher growth. For example, Warner (2014) argues that just spending money on investment is not enough to boost growth. He points to cases where poor investment returns owing to inefficiencies and higher debt associated with the investment boom resulted instead in weaker growth. ${ }^{1}$

Perhaps as a result of this, empirical evidence on the impact of public investment on growth remains mixed. While individual infrastructure projects may often generate fairly high returns on investment, their impact on GDP growth is more uncertain. ${ }^{2}$ Calderón, Easterly, and Servén (2003) argue that reductions in infrastructure spending in Latin America in the 1990s significantly reduced long-term growth prospects (e.g., by about 3 percentage points (or p.p.) a year in Brazil, and between 0.5 and 2 p.p. a year in Chile, Mexico, and Peru) and widened the per capita output gap with East Asian countries. Calderón and Servén (2010) estimated that African countries could also boost annual economic growth by approximately 1.5 p.p. per year by cutting in half their infrastructure deficit with respect to other regions of the world. Briceño-Garmendia, Estache, and Shafik (2004) show that of 102 studies that have estimated the impact of infrastructure investment on productivity or growth, 53 percent argue for a positive effect, 42 percent for no significant effect, and 5 percent for a negative effect. $^{3}$

Our paper seeks to contribute to the debate on the growth and debt impact of public investment for three fast-growing Southeast Asian economies: Cambodia, Sri Lanka, and Vietnam. We use a

\footnotetext{
${ }^{1} \mathrm{IMF}$ (2016) uses the GIMF model for generic large open economies to show that effectively managed public investment has a durable effect in increasing potential output.

${ }^{2}$ Sturm, Kuper and De Haan (1998) and De Haan, Romp, and Sturm (2007) survey the empirical and theoretical literature on the subject.

${ }^{3}$ In multiple country studies, 40 percent of countries showed a positive effect, 50 percent showed no significant effects, and 10 percent showed a negative effect. In contrast, all 12 single-country developing country studies showed a positive effect. Other studies on the impact of public investment on growth have not produced such clear-cut results (IMF 2004 and IMF 2005).
} 
dynamic small open economy model calibrated to fit the singularities of these economies to explore the macroeconomic tradeoffs of alternative public investment scaling up, revenue collection, and debt financing scenarios. Extending the model developed by Buffie et al. (2012), we include alternative financing instruments and allow for inefficient tax revenue collection, and time-varying inefficiencies in public investment. We assume efficiency improves when the government invests gradually -it has time to learn how to better allocate resources and implement structural reforms, the "investing in investing" suggested by Collier (2007) — which is not the case when the government rushes into a big push investment program. The tax revenue authority also benefits from these reforms and its ability to enforce tax collection improves commensurately. Hence, the model allows us to analyze the relevance of structural measures improving revenue collection as a valuable complement to fiscal adjustment and borrowing.

These three countries were chosen because they share common key characteristics for the purpose of this study: (i) their public capital stock is lower than the average of emerging and developing Asia (EDA) and they would therefore benefit from scaling up public infrastructure investment; and (ii) their public infrastructure and investment efficiency parameters are also lagging behind the EDA average. We use this information together with country-specific constraints and characteristics to calibrate the model, and draw conclusions about the preferable financing strategy for scaling up public investment. We do not seek to identify an optimal infrastructure investment threshold, compute the average infrastructure spending financing gap for the countries under analysis, or to make pronouncements about the allocation of investments to specific sectors. However, there are several papers discussing public investment in each of the three case countries that have identified the sectors with the greatest needs for investment (Cambodia: transport; Sri Lanka: water and sanitation; Vietnam: transport and electricity), highlighted the need for complete legal, policy, and regulatory frameworks and institutional reform, and pointed to investment inefficiencies as the most important infrastructure challenge going forward (Biller and Nabi, 2013; CBoSL, 2012; ADB, 2011; van Arkadie, 2010; Dapice and Thanh, 2009; Sum, 2008).

The paper concludes that a more gradual investment strategy is preferable to a front-loaded investment strategy. Regardless of the combination of financing, the more gradual strategy delivers higher growth for a given scaling-up of investment, thanks to the positive impact of "learning by doing" on the efficiency of public capital accumulation. As for the composition of financing, although the model simulations show that external financing produces the largest increase in real GDP over the long term, increasing the efficiency of revenue collection with additional borrowing and fiscal adjustment leads to the best macroeconomic outcome. In fact, the medium term is fraught with risks if the government relies solely on external borrowing, ranging from large real appreciations damaging the tradable sector to the possibility of far greater external borrowing costs as a result of increasing country risk premium. Given these caveats, the combination of higher indirect taxes (VAT) and borrowing (mostly external) could be more preferable. That combination delivers similar GDP growth but generates lower debt levels and ensures a lower risk of debt distress altogether. Nonetheless, for countries with already high debt levels, this strategy could still entail a too high risk to debt sustainability. We therefore emphasize importance of improving the efficiency of revenue collection: increasing the efficiency of tax revenue collection allows to finance the same amount of investment with much lower debt levels and lower statutory tax rates, reducing the distortionary effect on consumption and investment, and thus 
boosting growth and reducing the risk to debt sustainability.

The remainder of the paper is structured as follows: section II gives an overview of where Cambodia, Sri Lanka, and Vietnam stand in comparison with their peers with regards to public investment and its efficiency as well as to tax revenue collection and its effectiveness; section III introduces the model economy, while section IV discusses its calibration; and section V presents the results of our experiments. Section VI concludes the paper.

\section{Public Investment, Revenue Collection, and their Efficiencies}

The growth impact of increased public investment depends on a number of factors, including the efficiency of public investment and productivity of tax collection, the structure of financing, and the speed and size of public investment scaling up. A high level of investment does not necessarily guarantee a high growth impact if the investment projects are poorly designed, executed or allocated. In the same vein, financing of higher investment may carry high costs that could partly or fully offset the growth benefits of the new investment. New borrowing to finance investment could push public debt to a level that calls into doubt its sustainability, increasing borrowing costs and reducing fiscal policy's room for maneuver. Alternatively, increasing statutory tax rates to finance new investment projects could lead to higher tax-induced distortions and output costs. This section provides some background information about the countries' capital stock and their efficiencies, about revenue collection and about constraints that affect the choice of financing.

During the last 25 years, public investment levels have been generally increasing in the three countries (Figure A.1, Appendix). Sri Lanka's public investment jumped from around 2 percent of GDP during 1990-2004 to around 4-5 percent since then, though it remained below the average level of 6-7 percent in EDA. Cambodia's and Vietnam's public investment consistently exceed Sri Lanka's level by a significant margin, and in recent years reached about the same level as in EDA (at about 8 percent). ${ }^{4}$ Interestingly, the picture drastically changes for private investment (Figure A.2). Cambodia's private investment levels are quite low compared to those in Vietnam and Sri Lanka. In theory, increased public capital should increase the rate of return of private capital (i.e. the marginal product of private capital), and thus stimulate more private investment.

As for the stock of public capital, all three countries lag behind the EDA average and display diverging trends (Figure A.3). Vietnam has now the highest public capital stock at around 60 percent of GDP and its level has been increasing consistently during the whole period. Cambodia's public capital stock is marginally lower than in Vietnam, in sharp contrast to the 1990s when it was significantly higher. Following a persistent decline during 1990-2006, it has been increasing more recently. Sri Lanka's public capital stock is now lowest among the three countries and, like in Cambodia, had been on the decline during 1990-2008. Only recently has its level stabilized, but it remains at about one

\footnotetext{
${ }^{4}$ The story is similar for real GDP growth. In Cambodia and Vietnam, real GDP growth was broadly similar or higher than EDA average. On the other hand, real GDP growth in Sri Lanka has been consistently lower, though it picked up after the end of the civil war in 2009.
} 
half of the average for EDA.

Turning to the efficiency of public investment, it depends on a number of institutional factors, such as the quality of project selection, management and evaluation, and of the regulatory and operational frameworks (IMF, 2009). Often, these institutions and frameworks are relatively weak in developing countries, potentially reducing the productivity of public investment and public capital. Gupta et al. (2011) explicitly account for efficiency and show that public capital is a significant contributor to economic growth. The quality of public investment, as measured by variables capturing the adequacy of project selection and implementation, are shown to be statistically significant in explaining variations in economic growth, a result mainly driven by low-income countries. The role of efficiency is also confirmed in Warner's (2014) analysis of investment booms. He shows that on average there is only a weak positive association between investment spending and growth, and only in the same year as lagged impacts are not significant. On the other hand, Berg et al. (2015) argue that countries with low public investment efficiency must have a higher marginal product of public capital and hence tend to see the same growth impact from public investment scaling up as high efficiency-low return countries. They suggest however that "investing in investing" with structural reforms improving investment efficiency can have a significant impact on growth.

There are several approaches to measuring the efficiency of public investment. First, the IMF introduced the Public Investment Management Assessment (PIMA, IMF 2015) framework-a comprehensive measure of the strength of public investment management (Figure 1). Three pillars are surveyed (planning, allocating, and implementing) and 15 areas are assessed across more than 25 countries. Relative to its neighbors, Cambodia has the most room for improvement in each of the identified areas, scoring consistently below the EDA average. For instance, Cambodia would significantly benefit from improvements in the areas of monitoring of public assets, fiscal rules, and multiyear budgeting. While the IMF has not yet carried out a complete PIMA for Vietnam, our initial analysis points to deficiencies in the phases of project appraisal and transparency. Sri Lanka scores the highest overall and on nearly all aspects it is faring better than the EDA average. ${ }^{5}$

Complementing the countries' PIMA framework, the IMF also looks at four indicators: volatility of investment (measured by the standard deviation of it), the implementation of budgeted capital expenditures (measured by an average absolute percent deviation from planned budget), integrity (captured by the corruption perception index), and churn (IMF, 2015). ${ }^{6}$ The three countries' scores are close to the EDA average for churn, though Sri Lanka is slightly lower (Figure A.4). Regarding the volatility of investment, high volatility indicates that there is not a good medium-term budget framework or planning. Vietnam scores well on that measure, while Sri Lanka and Cambodia are at or near the EDA average. Cambodia and Vietnam perform best in their budget implementation, with

\footnotetext{
${ }^{5}$ Each country's PIMA score was rated by IMF staff on 45 aspects of the 15 institutions/areas within three phases of the investment process: planning, allocation, and implementation. Ratings are based on the country's laws and practices according to whether criteria for strong PIM institutions are fully met, partly met, or not met (i.e. between 0 (no key features in place) and 10 (all 45 key features fully in place)). The farther from the center, the stronger is a country's public investment management. The methodology is further discussed in Annex IV of the IMF's 2015 Paper, "Making Public Investment More Efficient."

${ }^{6}$ Churn is the measure of the year-on-year change in distribution of government investment between the nine nondefense sectors, in which a higher churn indicates greater flexibility of the budget and a lower churn indicates budget rigidity.
} 
Figure 1: Strength of public investment management and efficiency
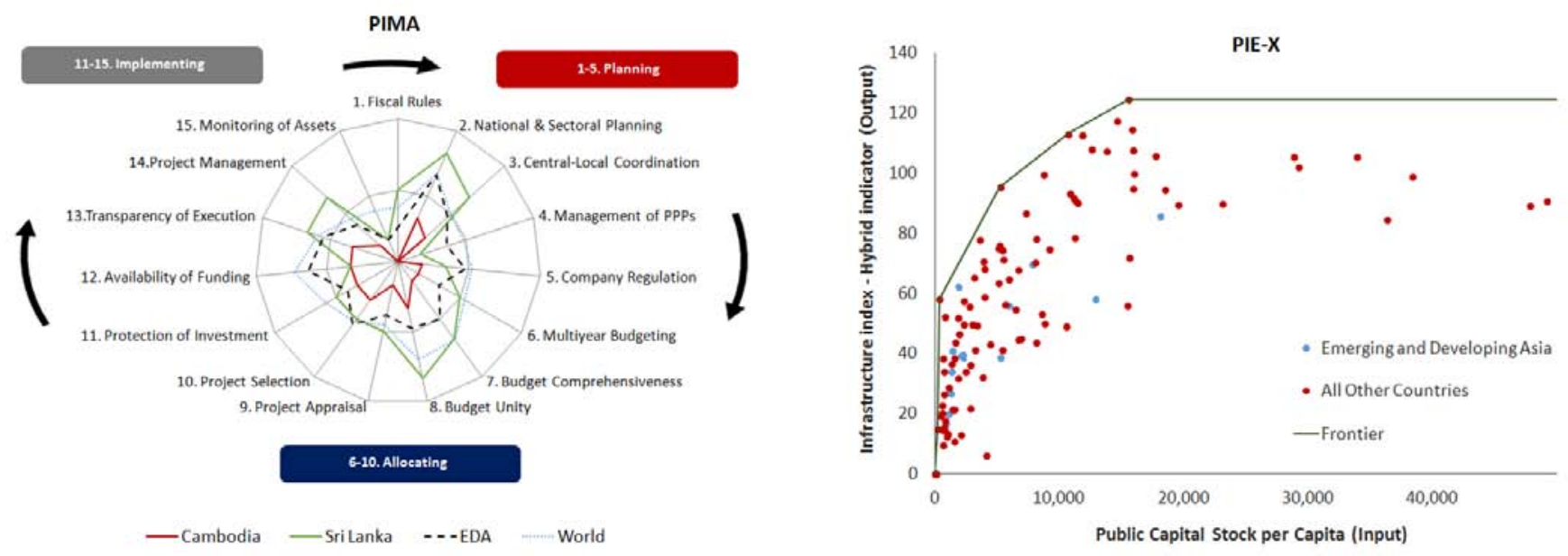

Source: IMF staff estimates.

much lower deviations of actual capital spending from the budgeted. Sri Lanka, on the other hand, seems to deviate more from its budgeted capital spending than its peers in the EDA group. However, Sri Lanka also performs significantly better than its peers in its integrity score.

An alternative measure of a country's ability to transform public investment into quality infrastructure is provided by the Public Investment Efficiency indicator (PIE-X). ${ }^{7}$ The PIE-X estimates confirm that there is substantial scope for improving public investment efficiency in all three countries, but more so in Cambodia. Its efficiency gap is the greatest owing mainly to weaker physical indicators of infrastructure in all fronts. Sri Lanka is very close to the efficiency frontier, having better infrastructure parameters than the EDA average thanks to the substantial revamping of roads, logistics, and public education and health infrastructure (Figure A.5). Vietnam's efficiency lies in between these countries - though lower than the EDA average.

Tax revenue collection in the three economies displays diverging trends as well (Figure A.6). On the one hand, Sri Lanka's government revenues have been steadily declining since mid-1990s, from about 20 percent of GDP to below 15 percent of GDP, and are presently the lowest among the three countries. In contrast, Cambodia's revenues have been steadily climbing, from less than 10 percent of GDP to above 15 percent of GDP, and in 2007 surpassed Sri Lanka's revenues. Vietnam has been consistently the strongest performer, with government revenues in the range of 20-25 percent of GDP. Even though they have fallen sharply in recent years, they still remain the highest in our group. For

\footnotetext{
${ }^{7}$ The methodology is based on the above-mentioned 2015 IMF report. For over 100 countries, the new Public Investment Efficiency indicator (PIE-X) estimates the relationship between the public capital stock and indicators of access to and the quality of infrastructure assets. Countries with the highest levels of infrastructure coverage and quality (output) for given levels of public capital stock and income per capita (inputs) form the basis of an efficiency frontier and are given a PIE-X score of 1 . Countries are given a PIE-X score of between 0 and 1 , based on their vertical distance to the frontier relative to peer best performers. The less efficient the country, the greater the distance from the frontier, and the lower its PIE-X score.
} 
comparison, Sri Lanka's government revenues are now less than the average for low-income countries in Asia, while Cambodia is at the same level and Vietnam above. All three countries are below the average of both emerging markets globally and emerging Asia.

The efficiency of revenue collection can be measured by looking at how much revenue is collected for a given tax rate. Higher tax efficiency allows to collect a greater amount of revenues with the same tax rates. As higher tax rates have a distortionary impact on consumers' and producers' decisions, the ability to increase revenues without having to resort to higher statutory tax rates reduces the adverse effect on growth. Therefore, a more efficient tax system should allow to finance the increase in public investment with less distortions that would weaken its positive impact on future growth. Figure 2 shows tax productivity for corporate income tax (CIT), personal income tax (PIT) and value added tax (VAT). Vietnam has the highest tax productivity for all three tax categories (for VAT, it even exceeds the average Asian tax productivity), while Sri Lanka has the lowest tax productivity and Cambodia is in the middle. This ranking mirrors the one implied by the tax revenue-to-GDP ratio.

Figure 2: Efficiency of revenue collection
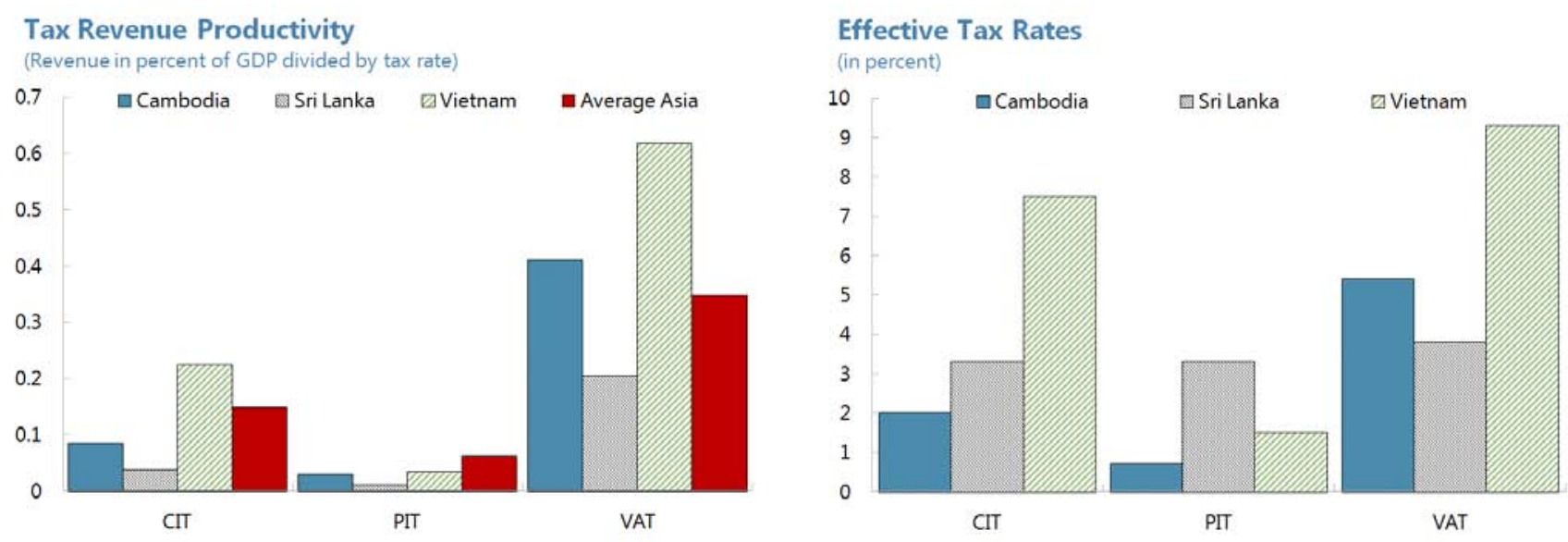

Source: IMF staff estimates; data for 2014.

In addition to the efficiency of investment and productivity of tax collection, other initial conditions have implications for the discussion of which investment scaling up strategy is most favorable. The most important is the level of public debt, which could pose a constraint to the borrowing-based strategy of financing investment scaling up. Looking at the stock of public debt, Cambodia is the least indebted among the three countries, while Sri Lanka is the most indebted amongst the comparable set (Figure A.7). Although the debt levels in Vietnam are lower than in Sri Lanka, Vietnam has relatively high debt compared to the EDA average. Cambodia's low debt levels reflects the country's long standing donor-based concessional financing and very limited access to borrowing in both domestic and international debt markets. 


\section{The Model}

We extend the model presented in Buffie et al. (2012) to explore Cambodia, Sri Lanka, and Vietnam's public investment avenues and their consequent macroeconomic effects under different financing scenarios. We add alternative financing instruments and allow for learning by doing in public capital accumulation and time-varying inefficiencies in tax revenue collection. The model features two types of households, two productive sectors, and a government that provides transfers to households, sets taxes on consumption, labor income, and profit, and resorts to domestic and external debt to cover its fiscal gap. ${ }^{8}$

\section{Households}

The two types of households, savers and liquidity-constrained (denoted by $\mathfrak{s}$ and $\mathfrak{c}$, respectively), consume domestic nontradable goods $c_{n, t}$ and tradable goods produced domestically $c_{x, t}$ and abroad $c_{m, t}$. These are combined into a constant elasticity of substitution (CES) function forming the consumption basket

$$
c_{t}^{i}=\left[\left(\rho_{n}\right)^{\frac{1}{\epsilon}}\left(c_{n, t}^{i}\right)^{\frac{\epsilon-1}{\epsilon}}+\rho_{m}^{\frac{1}{\epsilon}}\left(c_{m, t}^{i}\right)^{\frac{\epsilon-1}{\epsilon}}+\rho_{x}^{\frac{1}{\epsilon}}\left(c_{x, t}^{i}\right)^{\frac{\epsilon-1}{\epsilon}}\right]^{\frac{\epsilon}{\epsilon-1}} \text { for } i=\mathfrak{s}, \mathfrak{c},
$$

where $\rho_{m}, \rho_{n}$, and $\rho_{x}$ are CES weight parameters - for which $\rho_{n}=1-\rho_{x}-\rho_{m}$-and $\epsilon$ is the intratemporal elasticity of substitution between consumption goods. Households' demand for each consumption $\operatorname{good} c_{j, t}^{i}=\rho_{j}\left(\frac{P_{j, t}}{P_{t}}\right)^{-\epsilon} c_{t}^{i}$ for $j=m, n, x$ and $i=\mathfrak{s}, \mathfrak{c}$ is derived from minimizing total consumption expenditures with the economy's consumer price index defined $\operatorname{as}^{9}$

$$
P_{t}=\left[\rho_{n} P_{n, t}^{1-\epsilon}+\rho_{m} P_{m, t}^{1-\epsilon}+\rho_{x} P_{x, t}^{1-\epsilon}\right]^{\frac{1}{1-\epsilon}} .
$$

Given the consumption basket defined above, savers solve the intertemporal optimization problem

$$
\max \mathbb{E}_{t} \sum_{t=0}^{\infty} \beta^{t}\left(\frac{\left(c_{t}^{\mathfrak{s}}\right)^{1-1 / \varsigma_{c}}}{1-1 / \varsigma_{c}}-\kappa \frac{\left(l_{t}^{\mathfrak{s}}\right)^{1+1 / \varsigma_{n}}}{1+1 / \varsigma_{n}}\right)
$$

where $\varsigma_{c}$ is the intertemporal elasticity of substitution of consumption and $\varsigma_{n}$ the intertemporal elasticity of substitution of labor supply. The discount factor is $\beta=(1+\varrho)^{-1}$ with $\varrho$ as the rate of time preference. Savers spend their income on consumption goods, on private tradable and nontradable capital (investing $i_{x}$ and $i_{n}$, respectively), on fees for using public infrastructure $\mu z^{e}$, on CPI-indexed domestic bonds $b$, and on interest on foreign debt $b^{*}$ at the real interest rate $r^{*}$. Their income stems from their employment wage $w l^{\mathfrak{s}}$, interest received from tradable and nontradable capital (paying interest $r_{x}$ and $r_{n}$, respectively), interest received on domestic bonds (paying real interest rate $r$ ), as well

\footnotetext{
${ }^{8}$ Although relevant for industrialized economies as Kaldor (1961) shows, we assume the model does not have a balanced growth path and therefore compatible with households' separable preferences (King, Plosser, and Rebelo (1998)).

${ }^{9}$ The consumer price index of the composite good produced abroad $P_{t}^{*}$ is the numeraire.
} 
as profits $\Phi^{\mathfrak{s}}$ from domestic firms, and a fraction of remittances $\mathcal{R}$ and government transfers $\mathcal{T}$ dependent on their size in the labor market $\left(a=\frac{\mathfrak{c}}{\mathfrak{s}}>0\right.$ represents the proportion of liquidity-constrained households in the economy). The budget constraint is thus represented by

$$
\begin{aligned}
\left(1+\tau_{t}^{c}\right) P_{t} c_{t}^{\mathfrak{s}}+\mu z_{t-1}^{e}+P_{t} b_{t}^{\mathfrak{s}}+\left(1+r_{t-1}^{*}\right) b_{t-1}^{\mathfrak{s} *}+ & \\
\Theta_{t}^{\mathfrak{s} *}+P_{k, t}\left(i_{n, t}^{\mathfrak{s}}+i_{x, t}^{\mathfrak{s}}+A C_{n, t}^{\mathfrak{s}}+A C_{x, t}^{\mathfrak{s}}\right) \leq & \left(1-\tau_{t}^{l}\right) w_{t} l_{t}^{\mathfrak{s}}+r_{n, t} k_{n, t-1}^{\mathfrak{s}}+r_{x, t} k_{x, t-1}^{\mathfrak{s}}+b_{t}^{\mathfrak{s} *}+ \\
& \left(1+r_{t-1}\right) P_{t} b_{t-1}^{\mathfrak{s}}+\frac{1}{1+a}\left(\mathcal{R}_{t}+\mathcal{T}_{t}\right)+ \\
& \vartheta_{t}^{c} \tau_{t}^{c} P_{t} c_{t}^{\mathfrak{s}}+\vartheta_{t}^{l} \tau_{t}^{l} w_{t} l_{t}^{\mathfrak{s}}+\Phi_{t}^{\mathfrak{s}}
\end{aligned}
$$

Savers pay a value-added tax (VAT) $\tau^{c}$ on consumption and a tax $\tau^{l}$ on labor income (or personal income tax, PIT); however, they receive a lump-sum refund equivalent to a fraction of taxes paid in order to account for the difference between statutory taxes levied on them and the tax collected by the government as measured by $\vartheta^{c}$ and $\vartheta^{l}$. Households also face sectoral adjustment costs when investing $A C_{j, t}^{\mathfrak{s}} \equiv \frac{v}{2}\left(\frac{i_{j, t}^{\mathfrak{s}}}{k_{j, t-1}^{\mathfrak{s}}}-\delta\right)^{2} k_{j, t-1}^{\mathfrak{s}}$, as well as portfolio adjustment costs on external debt $\Theta_{t}^{\mathfrak{s} *} \equiv$ $\frac{\eta}{2}\left(b_{t}^{\mathfrak{s *}}-\overline{b^{\mathfrak{s *}}}\right)^{2}$, where $\overline{b^{\mathfrak{s *}}}$ is the steady-state value of external private debt.

These households also maximize their utility subject to the law of motion of capital, with $\delta_{k}$ as the depreciation rate

$$
k_{j, t}^{\mathfrak{s}}=\left(1-\delta_{k}\right) k_{j, t-1}^{\mathfrak{s}}+i_{j, t}^{\mathfrak{s}} \quad \text { for } j=n, x
$$

Solving the savers' constrained maximization problem with respect to $c_{t}^{\mathfrak{s}}, l_{t}^{\mathfrak{s}}, b_{t}^{\mathfrak{s}}, b_{t}^{\mathfrak{s} *}, i_{j, t}^{\mathfrak{s}}$, and $k_{j, t}^{\mathfrak{s}}$ for $j=x, n$, yields the consumption Euler equation

$$
c_{t}^{\mathfrak{s}}=\mathbb{E}_{t} c_{t+1}^{\mathfrak{s}}\left[\beta\left(1+r_{t}\right) \frac{1+\tau_{t}^{c}}{1+\tau_{t+1}^{c}}\right]^{-\varsigma_{c}},
$$

the labor supply

$$
\kappa\left(l_{t}^{\mathfrak{s}}\right)^{1 / \varsigma_{n}}\left(c_{t}^{\mathfrak{s}}\right)^{1 / \varsigma_{c}}=\frac{1-\tau_{t}^{l}}{1+\tau_{t}^{c}} \frac{w_{t}}{P_{t}},
$$

and the non-arbitrage conditions defining that the return on tradable and nontradable capital equals the real interest rate on domestic bonds

$$
\begin{aligned}
\left(1+v \Upsilon_{j, t}^{\mathfrak{s}}\right) \mathbb{E}_{t}\left(1+r_{t}\right)\left[\frac{P_{t+1}}{P_{t}} \frac{P_{k, t}}{P_{k, t+1}}\right]= & \beta \mathbb{E}_{t}\left[\frac{r_{j, t+1}}{P_{k, t+1}}-\frac{v}{2}\left(\Upsilon_{j, t+1}^{\mathfrak{s}}\right)^{2}+\right. \\
& \left.v \Upsilon_{j, t+1}^{\mathfrak{s}}\left[\frac{i_{j, t+1}^{\mathfrak{s}}}{k_{j, t}^{\mathfrak{s}}}+(1-\delta)\right]+(1-\delta)\right]
\end{aligned}
$$

where $\Upsilon_{j, t}^{\mathfrak{s}}=\left(\frac{i_{j, t}^{\mathfrak{s}}}{k_{j, t-1}^{\mathfrak{s}}}-\delta\right)$ for $j=n, x$, and that the real interest rate on domestic bonds equates the 
real interest rate on external private debt

$$
\mathbb{E}_{t}\left(1+r_{t}\right) \frac{P_{t+1}}{P_{t}}=\frac{\mathbb{E}_{t}\left(1+r_{t}^{*}\right)}{\left[1-\eta\left(b_{t}^{\mathfrak{s} *}-\bar{b}^{\mathfrak{s} *}\right)\right]},
$$

where $\eta$ governs the level of integration the private sector has in international capital markets. A low $\eta$ depicts the case in which the country has an open capital account with the private sector easily borrowing from abroad. The private sector pays a premium $u$ over the sovereign's interest rate on external commercial debt $r_{d c, t}, r_{t}^{*}=r_{d c, t}+u$.

Liquidity-constrained households have the same preferences as savers (enjoying consuming and leisure) but can only consume as much as their income from wages, remittances, transfers, and tax refunds received each period allow, i.e.

$$
\left(1+\tau_{t}^{c}\right) P_{t} c_{t}^{\mathfrak{c}}=\left(1-\tau_{l}^{l}\right) w_{t} l_{t}^{\mathfrak{c}}+\frac{a}{1+a}\left(\mathcal{R}_{t}+\mathcal{T}_{t}\right)+\vartheta_{t}^{c} \tau_{t}^{c} P_{t} c_{t}^{\mathfrak{c}}+\vartheta_{t}^{l} \tau_{t}^{l} w_{t} l_{t}^{\mathfrak{c}}
$$

\section{Firms}

Firms produce tradable and nontradable goods ( $y_{x}$ and $y_{n}$, respectively) according to a CobbDouglas production technology combining private capital $k_{j}$ and labor $l_{j}$, and government-supplied productive infrastructure $z^{e}$. Firms can only operate in one sector and benefit from a sector-specific total factor productivity (TFP) $A_{j}$. The government levies a tax on profit before capital income expenditures $\tau^{p}$ (or corporate income tax, CIT) in both sectors, a fraction of which $\left(\vartheta^{p}\right)$ is refunded to firms to capture the wedge between the tax burden on firms and government CIT revenues. In each sector $j$, a firm hence maximizes profits

$$
\Phi_{j, t}=\left(1-\tau_{t}^{p}\left(1-\vartheta_{t}^{p}\right)\right)\left[P_{j, t} y_{j, t}-w_{t} l_{j, t}\right]-r_{j, t} k_{j, t-1}
$$

where output is defined as

$$
y_{j, t}=A_{j, t}\left(z_{t-1}^{e}\right)^{\psi_{j}} k_{j, t-1}^{\alpha_{j}} l_{j, t}^{1-\alpha_{j}} \quad \text { for } \quad j=n, x .
$$

Firms can import machines $\mathfrak{m}_{m m}$ that are then combined with $a_{j}(j=k, z)$ units of a nontradable good (e.g., construction) to produce private capital (e.g., factories) and public infrastructure (e.g., roads). Their prices are given by $P_{k, t}=P_{m m, t}+a_{k} P_{n, t}$ and $P_{z, t}=P_{m m, t}+a_{z} P_{n, t}$, where $P_{n}$ is the (relative) price of the nontradable good and $P_{m m}$ the (relative) price of the imported machinery.

Firms maximize profit in a competitive environment, optimizing their demand for capital and labor satisfying

$$
\left(1-\tau_{t}^{p}\right) P_{j, t} \alpha_{j} \frac{y_{j, t}}{k_{j, t-1}}=r_{j, t} \quad \text { for } \quad j=n, x
$$

and

$$
P_{j, t}\left(1-\alpha_{j}\right) \frac{y_{j, t}}{l_{j, t}}=w_{t},
$$

where $w$ is the economy-wide wage and $r_{j}$ is the sectoral return on capital in sector $j$. While labor is 
perfectly mobile across sectors, returns on private capital are sector-specific - except when $k_{x}$ and $k_{n}$ are at the steady state for which $r_{x}=r_{n}$.

\section{Government}

Government revenues come from the VAT and PIT on households' consumption and labor income, CIT on firms' profits, and from fees collected from the savers' usage of infrastructure services (where $\mu=f \delta P_{z o}$, with $f$ representing a fraction of recurrent costs) that are then spent on transfers $\mathcal{T}$, debt service (where $r_{d}$ and $r_{d c}$ are the real interest rates on concessional and commercial loans), and infrastructure investment $\mathbb{I}_{z}$. While the real interest rate on concessional debt is constant $\left(r_{d, t}=r_{d}\right)$, the real interest rate on external commercial debt includes a risk premium capturing external public debt deviations from its steady state value, i.e. $r_{d c, t}=r^{f}+v_{g} e^{\eta_{g}\left(\frac{d_{t}+d_{c, t}}{y_{t}}-\frac{\bar{d}+\bar{d}_{c}}{\bar{y}}\right)} \cdot 10$

The government is allowed to have a fiscal deficit (i.e. when expenditures surpass revenues) that can be financed through grants $\mathcal{G}$ and a combination of tax adjustments and debt instruments: exogenous external concessional debt $\Delta d_{t}=d_{t}-d_{t-1}$ and domestic $\Delta b_{t}=b_{t}-b_{t-1}$ and external commercial $\Delta d_{c, t}=d_{c, t}-d_{c, t-1}$ debt following the decision rule $(1-v) \Delta b_{t}=v \Delta d_{c, t}$ as in Melina et al. (2016). The standard form for the government budget constraint is thus given by

$$
\begin{aligned}
P_{z, t} \mathbb{I}_{z, t}+\mathcal{T}_{t}+r_{t-1} P_{t} b_{t-1}+ & \\
r_{d, t-1} d_{t-1}+r_{d c, t-1} d_{c, t-1} \leq & P_{t} \Delta b_{t}+\Delta d_{t}+\Delta d_{c, t}+\tau_{t}^{c}\left(1-\vartheta_{t}^{c}\right) P_{t} c_{t}+\tau_{t}^{l}\left(1-\vartheta_{t}^{l}\right) w_{t} l_{t}+ \\
& \tau_{t}^{p}\left(1-\vartheta_{t}^{p}\right)\left[P_{n, t} y_{n, t}+P_{x, t} y_{x, t}-w_{t} l_{t}\right]+\mu z_{t-1}^{e}+\mathcal{G}_{t} .
\end{aligned}
$$

We can rewrite the budget constraint above in terms of the fiscal gap ( $\mathfrak{G} \mathfrak{a p})$ as

$$
\begin{aligned}
\mathfrak{G} \mathfrak{a p}_{t}= & P_{t} \Delta b_{t}+\Delta d_{c, t}+\left(\tau_{t}^{c}-\tau_{o}^{c}\right)\left(1-\vartheta_{t}^{c}\right) P_{t} c_{t}+\left(\tau_{t}^{l}-\tau_{o}^{l}\right)\left(1-\vartheta_{t}^{l}\right) w_{t} l_{t}+ \\
& \left(\tau_{t}^{p}-\tau_{o}^{p}\right)\left(1-\vartheta_{t}^{p}\right)\left[P_{n, t} y_{n, t}+P_{x, t} y_{x, t}-w_{t} l_{t}\right],
\end{aligned}
$$

where $\mathfrak{G} \mathfrak{a p} \mathfrak{p}_{t}=\mathfrak{E x p}_{t}-\mathfrak{R e v} \mathfrak{v}_{t}$, i.e. given by the difference between total expenditures and revenues when taxes are kept at their initial values $\left(\tau_{o}^{i}\right.$, for $\left.i=c, l, p\right)$ and concessional debt is exogenous, is covered by domestic and external commercial borrowing, and/or CIT, PIT, and VAT adjustments,

$$
\mathfrak{E x p}_{t}=P_{z, t} \mathbb{I}_{t}+\mathcal{T}_{t}+r_{t-1} P_{t} b_{t-1}+r_{d c, t-1} d c_{t-1}+\left(1+r_{d}\right) d_{t-1}-d_{t}
$$

and

$$
\mathfrak{R e v} \mathfrak{v}_{t}=\tau_{o}^{c}\left(1-\vartheta_{t}^{c}\right) P_{t} c_{t}+\tau_{o}^{l}\left(1-\vartheta_{t}^{l}\right) w_{t} l_{t}+\tau_{o}^{p}\left(1-\vartheta_{t}^{p}\right)\left[P_{n, t} y_{n, t}+P_{x, t} y_{x, t}-w_{t} l_{t}\right]+\mu z_{t-1}^{e}+\mathcal{G}_{t} .
$$

\footnotetext{
${ }^{10} r^{f}$ is the risk-free world interest rate and $y_{t}=P_{x, t} y_{x, t}+P_{n, t} y_{n, t}$ is nominal GDP. Note that if $v_{g}>0$ and $\eta_{g}=0$ the risk premium does not depend on public debt deviations.
} 
Taxes follow a rule $\left(\tau^{i}\right)^{\text {rule }}$ responding to tax and debt deviations from their targets up to a reasonable exogenous ceiling $\left(\tau^{i}\right)^{\text {ceiling }}$ such that the policy reaction is defined by

$$
\tau_{t}^{i}=\min \left\{\left(\tau_{t}^{i}\right)^{\text {rule }},\left(\tau^{i}\right)^{\text {ceiling }}\right\} \quad \text { for } \quad i=c, l, p,
$$

where

$$
\left(\tau_{t}^{i}\right)^{\text {rule }}=\tau_{t-1}^{i}+\lambda_{1, i}\left(\left(\tau_{t}^{i}\right)^{\text {target }}-\tau_{t-1}^{i}\right)+\lambda_{2, i} \frac{\left(P_{t-1} b_{t-1}+d_{c, t-1}\right)-\left(P b+d_{c}\right)^{\text {target }}}{y_{t}} \quad \forall \lambda_{1, i}, \lambda_{2, i} \geq 0
$$

and total nominal GDP is given by nominal sectoral outputs $\left(y=P_{n} y_{n}+P_{x} y_{x}\right)$. The speed of tax adjustments is given by $\lambda_{1, i}$, controlling the tax reaction to deviations from the tax target, and by $\lambda_{2, i}$, controlling the response to deviations from the debt target. Fiscal adjustment can be shared between CIT, PIT, and VAT according to the policy parameters $\lambda_{\tau_{l}}$ and $\lambda_{\tau_{p}}$, such that tax targets respond every period to the fiscal gap

$$
\begin{aligned}
\left(\tau_{t}^{c}\right)^{\text {target }} & =\tau_{o}^{c}+\left(1-\lambda_{\tau_{l}}-\lambda_{\tau_{p}}\right) \frac{\mathfrak{G} \mathfrak{a} \mathfrak{p}_{t}}{P_{t} c_{t}}, \\
\left(\tau_{t}^{l}\right)^{\text {target }} & =\tau_{o}^{l}+\lambda_{\tau_{l}} \frac{\mathfrak{G} \mathfrak{a} \mathfrak{p}_{t}}{w_{t} l_{t}}, \\
\left(\tau_{t}^{p}\right)^{\text {target }} & =\tau_{o}^{p}+\lambda_{\tau_{p}} \frac{\mathfrak{G} \mathfrak{a} \mathfrak{p}_{t}}{\sum_{j=n, x} P_{j, t} y_{j, t}-w_{t} l_{t}} .
\end{aligned}
$$

Public infrastructure investment includes cost overruns from absorptive capacity constraints (e.g. coordination issues or poor planning), such that investing $\$ 2$ million today or $\$ 1$ million today and $\$ 1$ million tomorrow are not equivalent, i.e. $\mathbb{I}_{z, t}=\left(i_{z, t}-\bar{\imath}_{z}\right) \mathcal{H}_{t}+\bar{\imath}_{z}$, where $\mathcal{H}_{t}=\left(1+\frac{i_{z, t}}{z_{t-1}}-\delta_{z}\right)^{\phi}$ only affects new investment projects $\left(i_{z, t}-\bar{\imath}_{z}\right)$ and $z_{t-1}$ is the current period stock of public capital. ${ }^{11}$ Society, on the other hand, only benefits from effectively produced capital $z_{t}^{e}$, which depends on public investment efficiency $s_{t} \in[0,1]$ and $z_{t}^{e}=s_{t} z_{t}$ such that one additional unit of public infrastructure investment may not translate into one unit of effective capital. Public capital evolves according to

$$
\begin{aligned}
z_{t} & =\left(1-\delta_{z}\right) z_{t-1}+i_{z, t}, \\
z_{t}^{e} & =\left(1-\delta_{z}\right) z_{t-1}^{e}+s_{t} i_{z, t},
\end{aligned}
$$

and public investment efficiency responds to deviations of public capital, capturing gains from investing gradually (e.g. learning how to invest more efficiently by investing with time $)^{12}$ controlled by the speed of efficiency gains $\varrho_{s}$

$$
s_{t}=\max \left\{s_{t-1}, s_{t-1}\left(\Delta z_{t}\right)^{\varrho_{s}}\right\} .
$$

Alternative approaches to model inefficiencies have been explored in Berg et al. (2013) and Melina et al. (2016), where investment efficiency falls when capital expenditures exceed a certain threshold. In

\footnotetext{
${ }^{11}$ Note that in the steady state $\left(1+\frac{\bar{n}_{z}}{\bar{z}}-\delta_{z}\right)^{\phi}=1$ given the steady state public capital $\bar{\imath}_{z}=\delta_{z} \bar{z}$.

${ }^{12}$ Note that $\Delta z_{t}=i_{z, t}-\delta_{z} z_{t-1}$, while in the steady state it is zero.
} 
the spirit of a concerted public financial management reform, we assume that the tax revenue authority becomes more capable of enforcing tax collection or less inclined to give tax breaks to households and

firms. One could think of additional public investment as contributing to building soft institutions or as the result of better management processes required by donors and lenders. The improved efficiency of revenue collection translates therefore into a lower tax revenue loss or a smaller wedge between statutory tax rates and effective tax rates

$$
\vartheta_{t}^{i}=\min \left\{\vartheta_{t-1}^{i}, \vartheta_{t-1}^{i}\left(\Delta z_{t}\right)^{-\varrho_{\tau}}\right\} \quad \text { for } \quad i=c, l, p
$$

\section{Aggregation and Market-Clearing Conditions}

Aggregating across both types of households and firms, we have $x_{t}=\sum_{\substack{i=\mathfrak{s}, \mathfrak{c} \\ j=n, x}} x_{t}^{i, j}$ for $x_{t}^{i, j}=$
\[ = \]

$c_{j, t}^{i}, l_{j, t}^{i}, i_{t}^{i}, k_{j, t}^{i}, A C_{j, t}^{i}, b_{t}^{i}, b_{t}^{i, *}, y_{j, t}, \Phi_{j, t}^{i}$. Labor markets clear with labor demanded in the tradable and nontradable sectors supplied by both types of households, i.e. $l_{x}+l_{n}=l^{\mathfrak{s}}+l^{\mathfrak{c}}=l_{t}$, and liquidityconstrained households' labor supply given by $l^{\mathfrak{c}}=a l^{\mathfrak{s}}$. Nontradable output must satisfy the value of the nontradable goods demanded by households and the public and private investment used in the process of building nontradable public and private capital (with weights $a_{k}$ for private investment and $a_{z}$ for public investment, as defined before)

$$
y_{n, t}=\rho_{n}\left(\frac{P_{n, t}}{P_{t}}\right)^{-\epsilon} c_{t}+a_{k}\left(i_{x, t}+i_{n, t}+A C_{x, t}+A C_{n, t}\right)+a_{z} \mathbb{I}_{z, t} .
$$

The balance of payment condition must hold as well

$$
\begin{aligned}
\Delta b_{t}^{*}+\Delta d_{c, t}+\Delta d_{t}+\mathcal{G}_{t}+\mathcal{R}_{t}=- & {\left[P_{n, t} y_{n, t}+P_{x, t} y_{x, t}-r_{t-1}^{*} b_{t-1}^{*}-\Theta_{t}^{\mathfrak{s *}}-\right.} \\
& -r_{d c, t-1} d_{c, t-1}-r_{d} d_{t-1}-P_{t} c_{t}- \\
& \left.P_{z, t} \mathbb{I}_{z, t}-P_{k, t}\left(i_{x, t}-i_{n, t}-A C_{x, t}-A C_{n, t}\right)\right]
\end{aligned}
$$

where the right-hand-side of (25) represents the current account deficit and the left-hand-side the capital account, i.e. $c a_{t}=-\Delta b_{t}^{*}-\Delta d_{c, t}-\Delta d_{t}-\mathcal{G}_{t}-\mathcal{R}_{t}$ (under a flexible exchange rate regime, $\Delta$ reserves $=0)$.

\section{Calibration}

We tailor the model to Cambodia, Sri Lanka, and Vietnam economies by calibrating parameters and the initial values of endogenous variables to match country-specific aggregates and trends (Table 1). We use annual data provided by central banks, finance ministries, the World Bank, and the IMF's 
World Economic Outlook and International Finance Statistics databases. ${ }^{13}$

Table 1: Selected initial values (\%)

\begin{tabular}{lcccc}
\multicolumn{1}{c}{ Definition } & Param. & Cambodia & Sri Lanka & Vietnam \\
\hline Public investment to GDP & $i_{z, o}$ & 8.1 & 4.8 & 7.4 \\
Public domestic debt to GDP & $b_{o}$ & 0.4 & 43.7 & 23.7 \\
Public concessional debt to GDP & $d_{o}$ & 33.4 & 21.0 & 2.5 \\
Public external (commercial) debt to GDP & $d_{c, o}$ & 0.0 & 8.3 & 21.6 \\
Real interest rate on domestic debt & $r_{o}$ & 1.5 & 1.5 & 1.5 \\
Real interest rate on concessional debt & $r_{d, o}$ & 0.0 & 0.0 & 0.0 \\
Real interest rate on public external debt & $r_{d c, o}$ & 0.2 & 0.6 & 0.6 \\
Grants to GDP & $\mathcal{G}_{o}$ & 3.0 & 0.1 & 3.5 \\
Remittances to GDP & $\mathcal{R}_{o}$ & 1.3 & 10.1 & 7.4 \\
Private external debt to GDP & $b_{o}^{*}$ & 8.0 & 22.2 & 7.1 \\
Corporate income tax (CIT) & $\tau_{o}^{p}$ & 20.0 & 17.5 & 20.0 \\
Labor income tax (PIT) & $\tau_{o}^{l}$ & 20.0 & 15.0 & 20.0 \\
Consumption tax (VAT) & $\tau_{o}^{c}$ & 10.0 & 15.0 & 10.0 \\
CIT revenue loss & $\vartheta_{o}^{p}$ & 90.0 & 81.0 & 62.7 \\
PIT revenue loss & $\vartheta_{o}^{l}$ & 96.5 & 78.2 & 92.6 \\
VAT revenue loss & $\vartheta_{o}^{c}$ & 46.0 & 74.6 & 7.0 \\
Public investment efficiency & $s_{o}$ & 32.1 & 85.2 & 70.4 \\
Return on public infrastructure investment & $R_{o}$ & 34.0 & 27.0 & 22.0 \\
\hline
\end{tabular}

Public infrastructure investment $\left(i_{z, o}\right)$ is set to 2014 levels and taken from the IMF World Economic Outlook. The gross return on public investment $R_{o}$ is based on Canning and Bennathan (1999) estimates of the social rate of return on infrastructure investments in the energy sector. Micro and macro estimates of the rates of return abound, with levels below $10 \%$ for advanced economies (e.g., Afonso and St. Aubyn (2008)) and between 15\% and 30\% for low-income countries (e.g., Foster and Briceo-Garmendia (2010)). In addition, the World Bank requires operations for approval to have internal rates of return of at least $12 \%$. Although our assumption is at the upper bound, it is consistent with a lower than the EDA average public capital stock to GDP (above 80\% vs. below 70\%, in 2005 PPP $\$$-adjusted). On the other hand, output elasticities with respect to sectoral effective infrastructure $\left(\psi_{n}\right.$ and $\left.\psi_{x}\right)$ are pinned down by the initial return on public infrastructure together with the restriction $\psi_{n}=\psi_{x}$, and therefore set at 0.176 for Cambodia, 0.222 for Sri Lanka, and 0.229 for Vietnam. ${ }^{14}$

The efficiency of public investment $\left(s_{o}\right)$ is deduced from the analysis of PIMA and PIE-X assessments discussed in section II. We set the initial values as the relative distance from one of the most efficient countries in the sample (Finland). While Sri Lanka and Vietnam levels are above the average Sub-Saharan economy efficiency used in Buffie et al. (2012), Cambodia's efficiency starts at a much

\footnotetext{
${ }^{13}$ Additional details on the calibration can be found in Buffie et al. (2012) and Table A.1 of the Appendix.

${ }^{14}$ Note that the lower past efficiency of public investment prevailed, the slower has effective public capital been accumulated and, therefore, the greater the marginal product of public capital is (i.e. its rate of return). While the inverse relationship between the initial level of efficiency and the marginal product of effective public capital is clear, we preferred to consider a more cautious level for Vietnam's output elasticity with respect to public capital and therefore assumed a lower rate of return on public infrastructure relative to Sri Lanka.
} 
lower level than the $60 \%$ used in their baseline. The efficiency gain parameter $\left(\varrho_{s}\right)$ is set at zero for the front-loaded investment scaling up (i.e. efficiency is fixed throughout time) and at 0.5 for the gradual investment profile, allowing efficiency to increase with time. We set the absorptive capacity parameter $(\phi)$ at the nonbinding level of zero and experience some departures from that in the first scenario.

Initial tax rates $\left(\tau_{o}^{i}\right)$ are set at their current statutory levels. The revenue loss variables are implicitly given by the difference between the effective tax rate and the statutory rate, such that $\tau_{o}^{i, \text { effective }}=\tau_{o}^{i}\left(1-\vartheta_{o}^{i}\right)$. The effective tax rate is given by the quotient of the specific tax revenue (CIT, PIT, or VAT) and a proxy of the tax base. In the case of VAT, the tax base used is private consumption from national accounts; and for CIT and PIT, we used the gross operating surplus and the compensation of employees, respectively, from the value added by cost component available in national accounts. The corporate income tax base for Vietnam was proxied by the manufacturing and retail sales implying an effective CIT rate of 7.5\%. A guesstimate was used for Cambodia such that the revenue loss matches an effective CIT rate of $2 \%$, while for Sri Lanka the effective rate stands at $3.3 \%$. Effective PIT rates for Cambodia, Sri Lanka, and Vietnam are 0.7\%, 3.3\%, and 1.5\%, respectively, justified by high income tax thresholds. Effective VAT rates are higher and closer to statutory rates at $5.4 \%, 3.8 \%$, and $9.3 \%$ for Cambodia, Sri Lanka, and Vietnam, respectively. The revenue collection efficiency gain parameter $\left(\varrho_{\tau}\right)$ mimics the public investment efficiency gain parameter $\left(\varrho_{s}\right)$. We further assume that only taxes share the burden of fiscal adjustment (i.e. $\lambda=0$ ) and that policy parameters adjusting the speed of convergence of taxes to their targets $\left(\lambda_{1, i}\right)$ are set to $25 \%$, while responses to debt deviations from its target are accommodated at a slower pace $\left(\lambda_{2, i}=2 \%\right)$.

Public debt levels $\left(b_{o}, d_{o}\right.$, and $\left.d_{c, o}\right)$ were taken from the IMF's 2015 debt sustainability analyses for the three countries matching 2014 data. Public concessional debt $\left(d_{o}\right)$ includes public non-commercial external debt. Private external debt $\left(b_{o}^{*}\right)$ corresponds to the latest data point available of the long term private nonguaranteed external debt series from the World Bank. Grants and Remittances $\left(\mathcal{G}_{o}\right.$ and $\mathcal{R}_{o}$, respectively) are taken from the IMF. Interest rates on debt instruments are set to match recent history. Nominal interest rates tend to be relatively low in these countries and discounting the inflation rates, real interest rates on public domestic and external debt $\left(r_{o}\right.$ and $\left.r_{d c, o}\right)$ lie below $2 \%$. The real interest rate on concessional debt $r_{d}$ is assumed to be zero.

From the remaining parameters held constant throughout the analysis, we highlight the following. For the share of liquidity-constrained households, we use the latest WB reported poverty headcount ratio at the national poverty lines (as \% of population; $9.6 \%$ in Sri Lanka and $17.2 \%$ in Vietnam) except for Cambodia (37.0\%), for which we used the poverty headcount ratio at $\$ 3.10$ a day (2011 $\mathrm{PPP}$, as $\%$ of population) for emcompassing a better guess of the share of the population with limited access to credit. Imports to GDP, used to pin down the share parameters in equation (1), are taken from the IMF as imports of goods for 2014 (i.e. $66.4 \%$ for Cambodia, 25.9\% for Sri Lanka, and 74.3\% for Vietnam). The value added in nontradable sectors, used to compute the share of output in the nontraded sector, are guesstimates from the sectoral aggregation of value added in national accounts. The fee savers pay on public infrastructure goods and services $(\mu)$ is a fraction of total recurrent costs. Given the considerable variation of these costs' weight on the final price of these services, we assume that the government charges $50 \%$ of its recurrent costs with public investments. The intertemporal elasticity of substitution of labor supply (Frisch elasticity) is set to 0.34 . 


\section{Policy Scenarios}

We use the model to answer several questions related to the public investment scaling up strategy. First, we study whether it is preferable to increase public investment gradually or more rapidly. Second, we look at the different options for financing the increased public investment: raising taxes (CIT, PIT, or VAT), borrowing (domestically or externally), or a combination of higher taxes and borrowing. Finally, we examine the case in which public investment efficiency gains are accompanied by improvements in the efficiency of revenue collection as a feasible complement to fiscal adjustment and borrowing.

\section{A. Investing gradually or aggressively}

A critical question in fiscal policy formulation or even in designing optimal fiscal anchors with debt considerations is whether the government should front-load its public investment plan or favor a more gradual profile. The timing indeed matters. In many low income countries and frontier markets capacity constraints or institutional bottlenecks may not allow for an efficient and productive use of huge front-loaded capital outlays. A slower investment pace may allow governments to learn how to better manage and allocate resources. Furthermore, a front-loaded investment program may be a drag on public finances, demanding a greater burden on households and firms today - via increased taxes - or on future generations - through substantial increases in debt levels.

To investigate this issue, we assume two alternative public investment paths for a cumulative increase equal to 20 percent of initial GDP: (i) the gradual profile, in which the government implements the investment program in 8 years (i.e. increasing the public investment-to-GDP ratio by 2.5 p.p. annually), with investment efficiency increasing over time (i.e. the efficiency gain parameter $\left(\varrho_{s}\right)$ is set at 0.5 , which means that for an additional unit of investment public investment efficiency increases by 0.5 ); and (ii) the front-loaded profile, in which the investment program is implemented in 4 years, peaking in the first year with an additional 5.6 p.p. and somewhat less in the second, third and fourth years, with insufficient time to improve the efficiency of spending. First, we consider the case in which the government finances its program solely through a combination of taxes $(1 / 2$ through VAT increases and $1 / 4$ through CIT and PIT increases, i.e. $\left.\lambda_{\tau_{l}}=\lambda_{\tau_{p}}=25 \%\right)$ and no additional borrowing is used. Secondly, we assume that the government finances the new investment entirely with either domestic or external commercial borrowing, and does not resort to any tax increase.

Figure 3 summarizes the result of the tax-based financing of the new investment, comparing the gradual and front-loaded investment programs. Both investment profiles require sizeable tax rate increases, reflecting the relatively low tax efficiency and narrow tax base discussed in section II. For all three countries, the gradual investment program results in higher GDP level over the medium term than the front-loaded program. Despite the distortionary effect of tax increases on private consumption and investment decisions, real GDP is projected to increase over the medium term (in 15 years) relative to its steady state level by 1.9 percent in Cambodia, 4.4 percent in Sri Lanka, and 3.0 percent in Vietnam (which is $0.9,1.8$, and 1.4 p.p. higher compared to the front-loaded scenario). 
While under the front-loaded program real GDP growth is initially higher than under the gradual program, these higher growth rates do not last and sustained gains in investment efficiency under the gradual program lead to a steady increase in real GDP growth. After 5-6 years, real GDP under the gradual program surpasses the real GDP level under the front-loaded scenario.

\section{Figure 3: Gradual versus front-loaded investment scaling up}
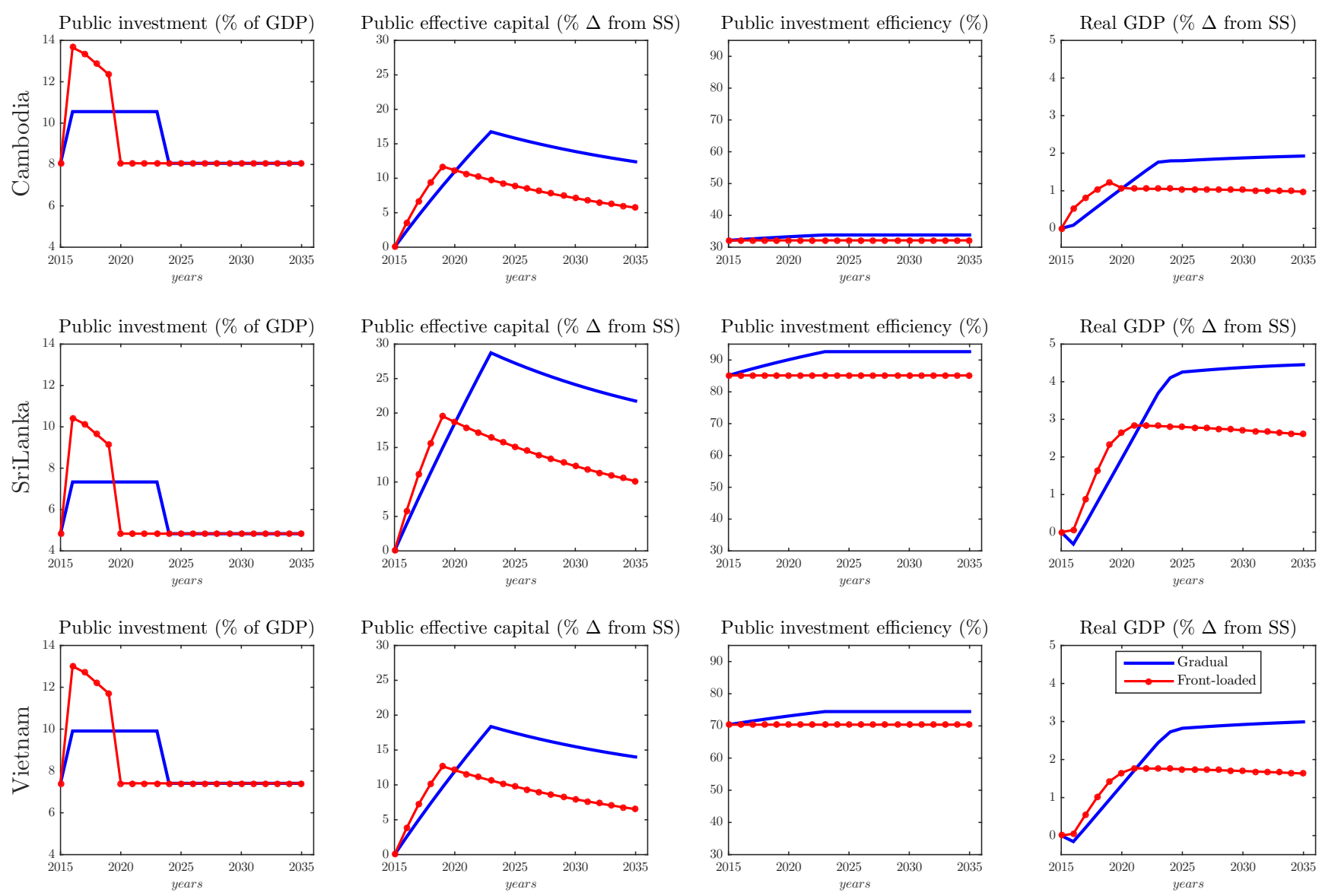

It is worth mentioning that to finance the gradual scaling up, the VAT rate will have to increase on average by 1.9 p.p. in the three countries, while the CIT and PIT rates will have to increase by 1.3 p.p. during the investment program. The front-loaded public investment program would require a notably higher increase in tax rates: by 4 p.p. for the VAT, and by about 3 p.p. for the CIT and PIT. ${ }^{15}$ These contrasts show the importance of combining alternative sources of funding for an ambitious investment program. Improving revenue collection and allowing the government to borrow domestically or externally may prove useful.

Figure 4 shows the result of the scenarios where the gradual and front-loaded investment programs are fully financed by either domestic or external borrowing (i.e. with no tax increases). While there was no borrowing in the previous scenario and the debt-to-GDP ratio declined with the increase in

\footnotetext{
${ }^{15}$ Adding additional absorptive capacity constraints (by setting $\phi>0$ ) further increases the required increase in tax rates, to compensate for the incremental costs of the investment program.
} 
GDP, financing the investment with domestic or external borrowing leads to a significant increase in public debt - both in the gradual and front-loaded scenarios. In all three countries, borrowing domestically leads to higher debt-to-GDP ratios relative to borrowing externally. In addition to being more expensive, relying on domestic debt crowds out private investment by competing for finite resources in the economy, which in turn slows down real GDP growth. This effect is particularly strong in the aggressive investment scenario with real interest rates on domestic debt increasing substantially. Similarly, in all three countries and for both domestic and external borrowing, the front-loaded investment strategy leads to a higher debt-to-GDP ratio compared to the gradual investment strategy. Furthermore, front-loading public investment with domestic borrowing leads to a fast-growing debt path, with the sharpest increase in Cambodia, where the public debt-to-GDP ratio doubles over 30 years. Unlike Cambodia, public debt in Sri Lanka and Vietnam eventually peaks and begins to decline under the domestic borrowing-financed gradual investment strategy. Still, for an extended period of time, public debt would remain above 90 percent of GDP in Sri Lanka and above 60 percent of GDP in Vietnam, raising issues of debt sustainability. ${ }^{16}$

\section{Figure 4: Resorting to debt is an alternative but sustainability risks exist}
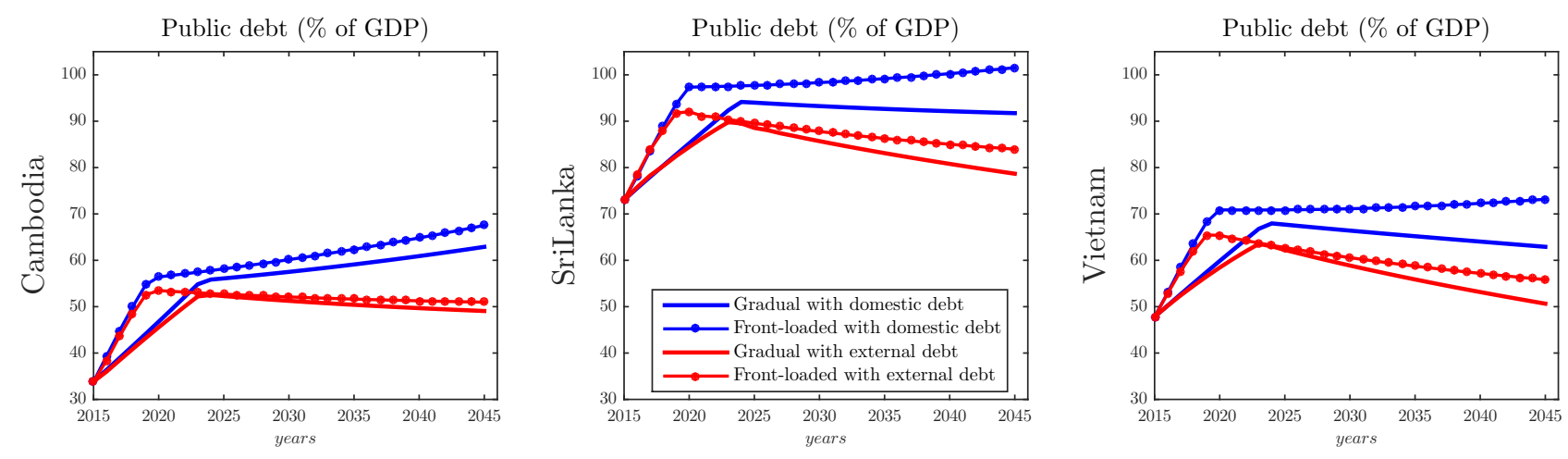

In contrast, externally-financed public investment scaling up allows the public debt-to-GDP ratio to stabilize at lower levels under both gradual and front-loaded scenarios, slowly declining in the case of Cambodia or relatively rapidly in the other two countries. The more favorable debt path reflects the lower real interest rate of external borrowing - with the caveat of assuming a constant country risk premium - and the non-crowding out effect on private consumption and private investment. However, while investment scaling up financed by external borrowing results in higher growth than with tax financing, it also leads to a real exchange rate appreciation that negatively impacts the traded goods sector. The price competitiveness loss - stronger with the front-loaded investment plan - slows down real GDP growth, which partly offsets the benefit of lower borrowing costs, though the increase in the relative price of nontraded goods favors the nontradable sector. Conversely, even though domestic public borrowing has higher costs, it can also have some positive side effects, such as promoting the

\footnotetext{
${ }^{16} \mathrm{~A}$ word of caution is in place here. Both Sri Lanka and Vietnam have high public debt but also large infrastructure needs. A way how to mitigate the tension between the need to invest (and borrow) more and the risks associated with a further increase of the already high public debt is to improve revenue collection. To the extent that revenues could be increased and investment financed in a non-distortionary manner, without a significant increase in debt, fiscal space could be created and growth could be supported without creating adverse market reactions and endangering fiscal sustainability.
} 
domestic financial market development.

\section{B. Combining borrowing and tax increases}

In the previous two sections, we established that the gradual scaling up of public investment is preferable to the front-loaded program and that under the assumptions of our model the investment scaling up financed by external borrowing can be achieved with lesser increase in public debt compared to domestic borrowing. To further illustrate the macroeconomic implications of public investment scaling up and provide guidance on policy options, in this section, we analyze the combination of tax increases with domestic and external borrowing to finance the investment program. As we have shown above that the gradual approach to investment scaling up is preferable to the front-loaded approach, we delve our analysis in what follows to the former.

Given the level of development of domestic financial markets and historical trends in both public domestic and external commercial debt, we assume that Cambodia would have to resort in the medium term to more domestic than external borrowing (i.e. $v=75 \%$ ), Vietnam would prefer more external borrowing $(v=25 \%)$, and Sri Lanka is indifferent between domestic and external commercial financing (i.e. $v=50 \%$ ). Furthermore, with access to borrowing, we assume that the three countries are postponing the tax increase during the first four years of the investment scaling up program and rely instead entirely on borrowing.

Figure 5 shows the debt and growth impact of all alternative financing options for the gradual scaling up scenario (a mix of tax increases (delayed by four years) and borrowing, only borrowing, and only tax increases) and Table 2 summarizes the results in terms of impact on average real GDP growth over 15 years for all the alternative financing options under both the gradual and aggressive investment profiles. ${ }^{17}$ We draw the following conclusions:

- Comparing the growth impact of public investment scaling up across the three countries under alternative financing scenarios, the highest increase in real GDP is observed in Sri Lanka, followed by Vietnam, and then Cambodia. In Sri Lanka, average annual real GDP growth over the medium term increases by 0.5-0.65 p.p., in Vietnam by about 0.35-0.45 p.p., and in Cambodia by about $0.25-0.31$ p.p.

- Comparing the impact of alternative financing scenarios in each country, the scaling up fully financed by external borrowing produces generally the highest increase in real GDP growth and level, though in Vietnam the combination of CIT increases and borrowing (mostly external) generates comparable real GDP gains in later years (yet the differences are small). It should be noted that external borrowing assumes a fairly constant risk premium (with $\eta_{g}=1$ ). A greater risk premium would substantially increase borrowing costs with higher levels of public debt, which would be particularly worrisome for Cambodia. Furthermore, while external borrowing

\footnotetext{
${ }^{17}$ For Cambodia, for instance, average real GDP growth in the tax-financed investment program is higher by 0.25 p.p. under the gradual scenario, and by 0.14 p.p. under the front-loaded scenario.
}

CInternational Monetary Fund. Not for Redistribution 
results in the highest increase in real GDP over the medium run, it also entails the highest volatility in growth rates. This is in particular the case for Cambodia, where the real GDP initially declines, before recovering sharply. Similar, though less pronounced, volatility could be observed in Sri Lanka and Vietnam as well. This is the result of the real exchange rate appreciation affecting the traded goods sector during the scaling up phase.

- In terms of impact on public debt, investment scaling up financed fully by domestic borrowing results in the highest increase in public debt-to-GDP ratio, by about 20 p.p. in Sri Lanka and Vietnam before it peaks and begins to decline. In Cambodia, the growth in public debt-to-GDP ratio eventually slows down, but the ratio continues to increase. In contrast, tax only financing leads to a slow decline in debt, as a result of increasing GDP. Interestingly, unlike in Sri Lanka and Vietnam, the debt ratio for Cambodia under the combination of increased taxes and borrowing, or under external borrowing only, broadly stabilizes but does not decline much. Given the initial constraint on tax increases, debt has to cover the fiscal gap generated by the public investment scaling up rising rapidly in the first four years. However, once governments adjust taxes, they have to do so more aggressively by increasing the VAT rate by 1.5 to 2.5 p.p., the CIT rate by 1.0 to 4.0 p.p., and the PIT rate by 1.0 to 3.7 p.p. for the following few years. These distortionary tax adjustments are costly for the economy and debt levels still have to increase substantially to finance the investment program. This is in line with IMF (2015), where the need to resort to distortionary taxation may actually dampen the foundations of future growth.

Table 2: Impact on growth and public debt after 15 years

\begin{tabular}{|c|c|c|c|c|c|c|c|c|}
\hline \multicolumn{2}{|c|}{ Scenario } & Taxes only & Dom. debt & Ext. debt & CIT/Debt & PIT/Debt & VAT/Debt & Taxes/Debt \\
\hline \multicolumn{9}{|c|}{ Cambodia } \\
\hline \multirow{2}{*}{ Gradual } & Avg. growth & 0.25 & 0.24 & 0.31 & $\mathrm{NF}$ & $\mathrm{NF}$ & 0.26 & 0.21 \\
\hline & $\Delta(D e b t / G D P)$ & -0.62 & 23.65 & 17.41 & $\mathrm{NF}$ & $\mathrm{NF}$ & 15.32 & 17.56 \\
\hline \multirow{2}{*}{ Aggressive } & Avg. growth & 0.14 & 0.13 & 0.22 & $\mathrm{NF}$ & NF & 0.12 & 0.09 \\
\hline & $\Delta(D e b t / G D P)$ & -0.34 & 26.30 & 18.25 & $\mathrm{NF}$ & $\mathrm{NF}$ & 21.78 & 21.95 \\
\hline \multicolumn{9}{|c|}{ Sri Lanka } \\
\hline \multirow{2}{*}{ Gradual } & Avg. growth & 0.57 & 0.56 & 0.65 & 0.56 & 0.53 & 0.60 & 0.56 \\
\hline & $\Delta(D e b t / G D P)$ & -3.02 & 20.26 & 12.70 & 13.47 & 13.71 & 14.42 & 13.42 \\
\hline \multirow{2}{*}{ Aggressive } & Avg. growth & 0.36 & 0.35 & 0.44 & $\mathrm{NF}$ & $\mathrm{NF}$ & 0.37 & 0.33 \\
\hline & $\Delta(D e b t / G D P)$ & -1.89 & 25.32 & 14.77 & $\mathrm{NF}$ & NF & 19.70 & 18.15 \\
\hline \multicolumn{9}{|c|}{ Vietnam } \\
\hline \multirow{2}{*}{ Gradual } & Avg. growth & 0.39 & 0.36 & 0.45 & 0.42 & 0.38 & 0.42 & 0.40 \\
\hline & $\Delta(D e b t / G D P)$ & -1.34 & 18.57 & 11.04 & 6.68 & 8.12 & 5.32 & 5.95 \\
\hline \multirow{2}{*}{ Aggressive } & Avg. growth & 0.23 & 0.21 & 0.30 & 0.25 & 0.26 & 0.27 & 0.24 \\
\hline & $\Delta(D e b t / G D P)$ & -0.79 & 23.29 & 12.75 & 15.70 & 16.07 & 12.94 & 10.64 \\
\hline
\end{tabular}

Note: Growth impact is the $15 \mathrm{y}$ average of the yearly real GDP growth rate (in additional p.p.); debt impact is the difference between debt-to-GDP ratio in $\mathrm{t}=15$ and initial value (in additional p.p.). In the top headings, taxes refer to the combination of taxes (CIT, PIT, and VAT) and debt to the

combination of domestic and external debt, according to the proportions described in the text. NF stands for not feasible, given the explosive debt path that strategy would generate.

A few additional points should be mentioned. The limited ability to collect CIT and PIT revenues and their relatively low tax base precludes these countries from using these instruments effectively- 
particularly with the front-loaded investment scaling up program. Cambodia, in particular, would not be able to use the combination of borrowing and CIT or PIT to finance the public investment scaling up since borrowing - mostly domestic - would need to increase significantly and these two taxes would strongly impair private investment (see column NF in Table 2). ${ }^{18}$ Increasing CIT rates reduces private returns on capital, while increasing PIT rates affect labor income, and both reduce private investment (with minor effects on private consumption).

Figure 5: Debt financing with tax adjustments is a sensible option
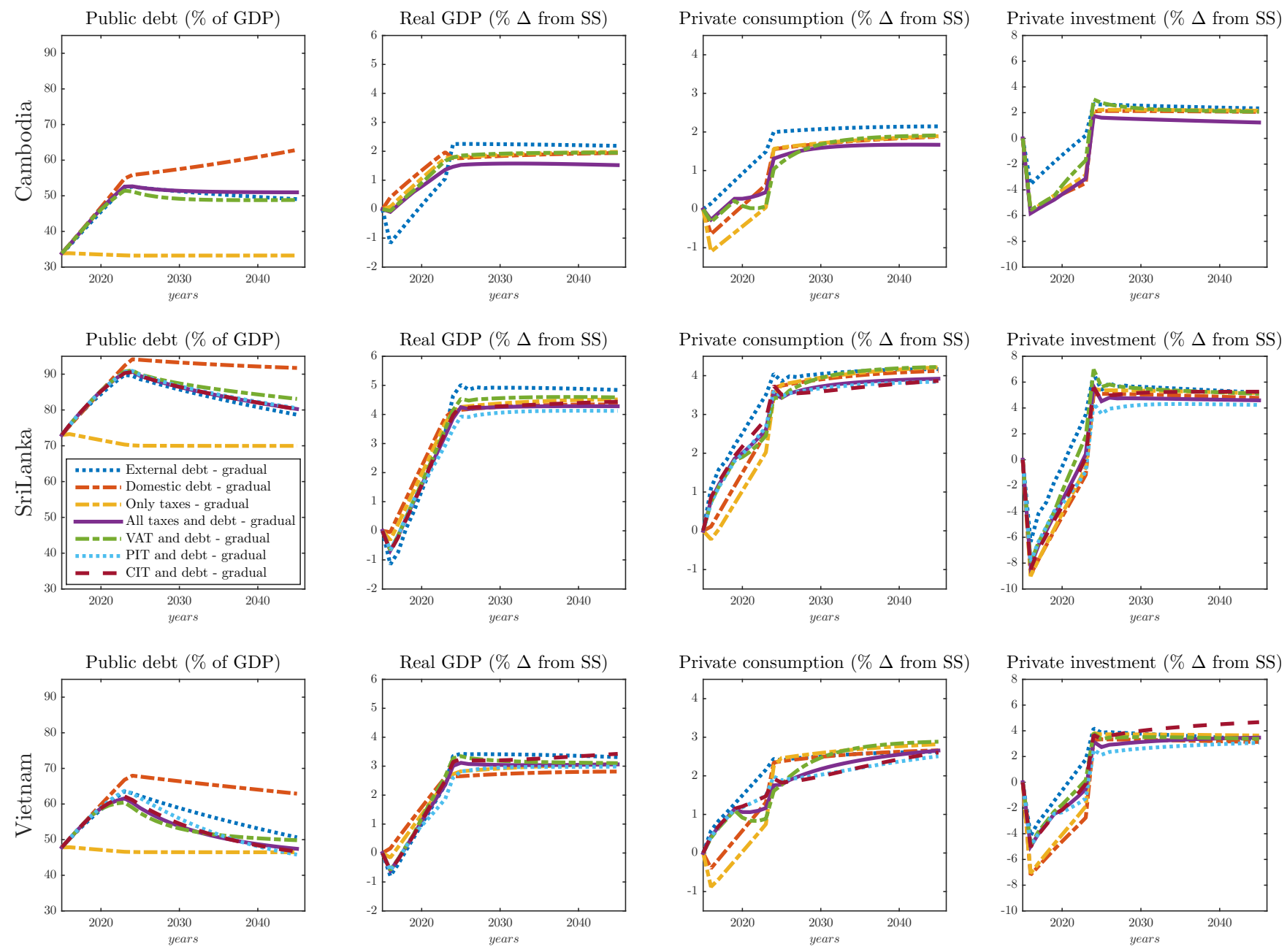

For several years, the impact on private investment growth is initially negative in both tradable and nontradable sectors (significantly so in the first year) - the initial crowding out effect of public investment. However, in the later years, private investment picks up significantly and its growth eventually surpasses the growth in real GDP with more public capital raising the marginal product of private capital - the crowding in effect. As discussed above, having predominantly domestic debt further reinforces the negative effect on private investment by pressuring the real interest rate on domestic bonds upwards. On the other hand, the impact on private consumption mirrors the impact

\footnotetext{
${ }^{18}$ However, combining CIT or PIT adjustments with solely external debt (or lower levels of domestic debt for that matter) would be a feasible option for Cambodia.
} 
on real GDP. Sri Lanka records the largest increase in private consumptions growth, followed by Vietnam and Cambodia. Furthermore, given the constraint on tax increases in the first four periods with borrowing, private consumption is not as impacted as in the only tax financing scenario.

\section{Improving tax revenue collection}

Finally, we look at the benefits that could be obtained from improving the efficiency of tax collection. In the section discussing the gradual versus front-loaded investment strategy, we introduced the concept of "learning by doing," the idea that governments learn how to become more efficient at deploying public investment. In this section we assume that improvements in public investment efficiency are also accompanied by enhancing tax collection. In other words, the government is able to collect more revenue from the same tax rates, thanks to improved tax administration, strengthened tax compliance or broadened tax base as a result of reductions in tax exemptions and special rates. The revenue collection efficiency gain parameter $\left(\varrho_{\tau}\right)$ is set at 0.5 across all taxes and is the same as $\varrho_{s}$, implying that the speed of revenue improvement broadly matches the speed of public investment efficiency improvement. As a result of revenue improvements, the gap between effective tax rates (tax collection divided by the tax base) and statutory rates becomes narrower.

Table 3: Effective tax rates at the end of the investment program (\%)

\begin{tabular}{cccc} 
Definition & Cambodia & Sri Lanka & Vietnam \\
\hline Effective CIT rate $\left(\tau_{8}^{p}\right)$ & $3.1(2.1)$ & $4.8(3.6)$ & $8.6(7.9)$ \\
CIT revenue loss $\left(\vartheta_{8}^{p}\right)$ & $85.5(90.0)$ & $74.5(81.0)$ & $59.3(62.7)$ \\
Effective PIT rate $\left(\tau_{8}^{l}\right)$ & $1.8(0.8)$ & $4.5(3.5)$ & $2.6(1.6)$ \\
PIT revenue loss $\left(\vartheta_{8}^{l}\right)$ & $91.6(96.5)$ & $71.9(78.2)$ & $87.5(92.6)$ \\
Effective VAT rate $\left(\tau_{8}^{c}\right)$ & $6.7(6.4)$ & $5.2(4.2)$ & $10.7(10.7)$ \\
VAT revenue loss $\left(\vartheta_{8}^{c}\right)$ & $43.7(46.0)$ & $68.6(74.6)$ & $6.6(7.0)$ \\
\hline
\end{tabular}

Table 3 compares the magnitude of the increase in effective tax rates as a result of improved revenue collection, using the gradual investment scaling up plan financed solely with tax adjustments. For example, in Cambodia, the effective CIT rate has increased after eight years (when the scaling up plan is complete) from 2.1 percent to 3.1 percent. Table 3 also shows the extent of implied revenue loss - the difference between the theoretical maximum collection (i.e. tax rate multiplied by tax base) and the actual collection. Looking again at the example of Cambodia, the improved efficiency of tax collection reduced the CIT revenue loss from 90 percent to 85.5 percent. With broadly the same statutory tax rate increase, governments are now able to collect more revenues, reducing some of the distortionary impact of taxes on consumption and investment decisions. The additional revenue gains are then used to pay off government borrowing, which in turns slows down the increase in statutory rates (by the fiscal rules defined in equation (16)). When the investment scaling up is fully financed by borrowing, the beneficial effect of improved tax collection does not matter; while in the scaling 
up strategy fully financed with tax increases, the improved tax collection efficiency would bring the largest gains.

Figure 6 below shows the impulse responses for the financing of the gradual investment plan assuming all taxes adjust and borrowing is endogenous (according to the split rule described in the previous section), comparing the cases with no improvement in tax revenue collection and with timeimproving revenue collection. In addition, Table 4 compares the 15-year average of annual real GDP growth as well as the difference between debt-to-GDP ratio in 15 years and initial values for the gradual scaling up scenario focusing on the financing with a mix of all taxes and borrowing.

Figure 6: Improving revenue collection reduces debt distress
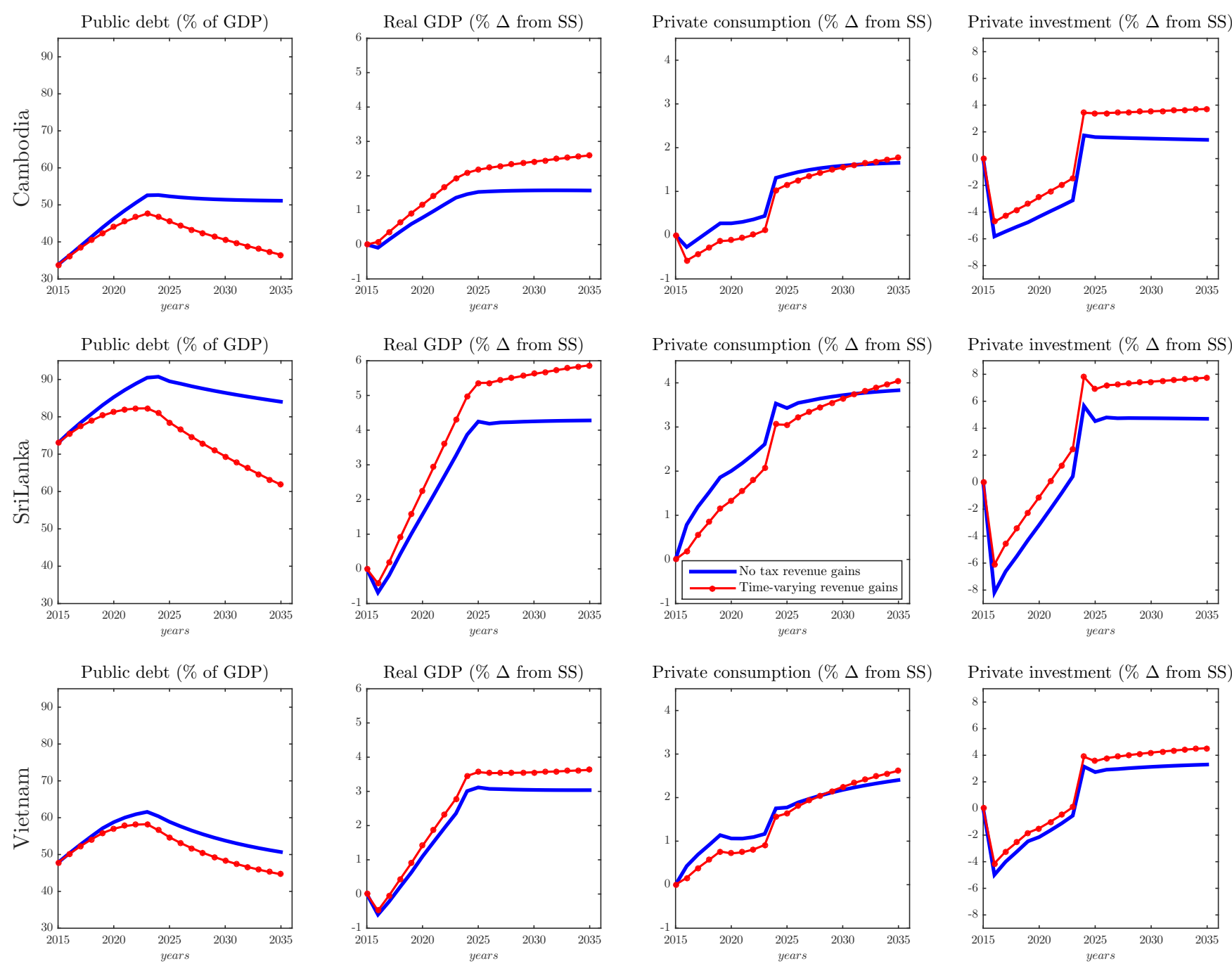

Note: Results are for the gradual investment profile with CIT, PIT, and VAT adjustments and both types of borrowing.

Improving tax revenue collection has over time a positive impact on growth and also significantly reduces the debt-to-GDP ratio. Improving revenue collection can lead to an additional 0.3 to 0.7 p.p. 
annually in real GDP growth, with major gains relative to the baseline gradual investment scaling up in Sri Lanka and Cambodia, where revenue losses are greater. The greater revenue collection efficiency increases growth because it demands lower domestic and external borrowing and therefore a slower statutory tax adjustment.

Since households and firms base their decisions on statutory rates, they do not perceive improving tax revenue collection as a tax increase. Although tax increases are distortionary in nature, improving tax revenue collection is not. Improving tax revenue collection is less pervasive than an increase in tax rates because private agents decisions are distorted by raising tax rates at the margin, while improving efficiency works as a decrease in lump-sum transfers towards Ricardian households. Nonetheless liquidity-constrained households are instantaneously affected by the improvement in revenue collection, justifying the small impact on private consumption. While this improvement does not distort consumption and savings decisions from Ricardian households and capital and labor demand from firms, it takes about fifteen years for private consumption in the scenario with efficiency gains to surpass private consumption without efficiency gains. Further increasing the fraction of liquidity-constrained households in this economy with improving revenue collection would have a greater impact on private consumption and reduce some of the benefits. In contrast, improved tax collection efficiency provides a sizable boost to private investment again with the highest in Sri Lanka, followed by Vietnam and Cambodia.

The benefits of revenue collection are more expressive when looking at debt-to-GDP ratios. We see modest increases in debt in Cambodia and Vietnam relative to their starting point, while in Sri Lanka the government is able to finance its gradual investment scaling up plan with a lower debt-to-GDP ratio than prior to when its investment program started. Relative to the gradual investment scaling up without improvements in tax efficiency, debt-to-GDP ratios can be 17 p.p. lower in Sri Lanka, 11 p.p. lower in Cambodia, and 5 p.p. lower in Vietnam 15 years after the start of the infrastructure investment program. The lower public debt-to-GDP ratio reflects both higher GDP and lower nominal debt, as the improved efficiency of tax collection reduces some of the distortionary effect of taxes and substantially reduces the need for borrowing. Thus, focusing on improving revenue collection should mitigate the difficult tradeoff between building up public capital and containing sovereign risks.

\section{Table 4: Revenue collection and impact on growth and public debt after 15 years}

\begin{tabular}{|c|c|c|c|}
\hline \multirow{2}{*}{ Scenario } & \multicolumn{3}{|c|}{ All Taxes and Debt } \\
\hline & Cambodia & Sri Lanka & Vietnam \\
\hline Avg. GDP growth & 0.33 & 0.73 & 0.46 \\
\hline$\Delta(D e b t / G D P)$ & 6.73 & -3.59 & 0.52 \\
\hline \multicolumn{4}{|c|}{$\begin{array}{l}\text { Note: Growth impact is the } 15 \mathrm{y} \text { average of the yearly real GDP growth } \\
\text { rate (in additional p.p.); debt impact is the difference between debt-to- } \\
\text { GDP ratio at } \mathrm{t}=15 \text { and initial value (in additional p.p.). In the top } \\
\text { headings, taxes refer to the combination of taxes (CIT, PIT, and VAT) } \\
\text { and debt to the combination of domestic and external debt, according } \\
\text { to the proportions described in the text. }\end{array}$} \\
\hline
\end{tabular}




\section{Concluding Remarks}

In this paper, we examined the impact of public investment scaling up on growth and debt sustainability, and analyzed how improving the efficiency of capital spending and of tax revenue collection affects macroeconomic variables. In a dynamic small open economy model, we contrasted different financing options for a sizeable public investment scaling up plan, including borrowing (domestic and external) and tax increases (both corporate and personal income tax and VAT). Through structural reforms, the government is able to improve the efficiency of public investment over time when investing gradually (the result of learning by doing) and the tax revenue authority becomes concomitantly more capable of enforcing tax collection or less inclined to give tax breaks. All these innovations are studied within one analytical framework applied to three fast-growing countries in Southeast Asia: Cambodia, Sri Lanka, and Vietnam - all aiming to address large infrastructure gaps, while maximizing the impact of public investment on growth and maintaining debt sustainability.

The main results of our paper can be summarized as follows. First, compared to front-loading investment spending, a gradual public investment profile is more favorable because we assume governments are able to accumulate experience dealing with major infrastructure projects, gradually improving the efficiency of public investment, and therefore accelerate public capital accumulation and growth; by contrast, front-loading investment can be costly considering lower efficiencies and the higher tax rates or borrowing needed to finance them. Second, model simulations suggest that although using only external financing would generate the highest increase in real GDP over the long run, increasing the efficiency of revenue collection with some borrowing and fiscal adjustment leads to the best macroeconomic outcome. In fact, the medium term is fraught with risks if the government relies solely on external borrowing. While it avoids the crowding out of private investment associated with domestic borrowing, the benefits could be oset by larger real exchange rate appreciations hampering the tradable sector. In addition, in particular for countries with already high external debt, country risk premia can increase and thus lower costs of external borrowing relative to domestic borrowing may not be realistically sustained. Therefore, we argue that combining tax increases with borrowing is a preferable strategy compared to external borrowing only but still leaves countries with high debt levels. Combining more external debt nancing - given the lower interest rates these operations have historically carried in those countries - with VAT increases - the most eciently collected tax - would produce higher growth rates and lower debt levels.

Finally, countries with low tax collection efficiency could have substantial room for improving tax revenue collection without significantly increasing tax rates. This would allow them to achieve higher GDP with lower debt-to-GDP ratios for the same levels of public investment scaling up. Sometimes overlooked for countries with relatively low revenue efficiency, improving the efficiency of revenue collection over time may ease the burden of fiscal adjustment and help policymakers efficiently meet the challenge of addressing large infrastructure gaps while maintaining debt sustainability.

For countries where the effective capital stock is low and where real infrastructure gaps exist, we have shown that a sizeable medium-term investment scaling up program, in particular in conjunction with reforms enhancing the efficiency of public investment and tax revenue collection, can lead to a

CInternational Monetary Fund. Not for Redistribution 
more favorable macroeconomic outcome relative to a big push investment program. All three countries have substantial room to improve on several fronts the efficiency of capital spending and the efficiency of tax revenue collection, which we have identified as important channels for solving the dilemma of burden sharing between current and future generations for a substantial scaling up of infrastructureyet enhancing growth and maintaining public debt sustainable. 


\section{References}

Abiad, A., Almansour, A. Furceri, D., Mulas Granados, C., and P. Topalova. 2014. "Is It Time for an Infrastructure Push? The Macroeconomic Effects of Public Investment." Chapter 3 in World Economic Outlook, October 2014. Washington: International Monetary Fund.

Afonso, A. and M. St. Aubyn, 2008, "Macroeconomic Rates of Return of Public and Private Investment: Crowding-In and Crowding-Out Effects." ECB Working Paper No. 864. Manchester School, Vol. 77, No. 51, pp. 21-39, 2009.

Asian Development Bank (ADB), 2011, "Cambodia: Transport Sector Assessment, Strategy and Road Map." Manila.

Berg A., Portillo, R., Yang, S., and L.F. Zanna, 2013, "Public Investment in Resource-Abundant Developing Countries." IMF Economic Review, 61, pp. 92-129.

Berg A., Buffie, E., Pattillo, C., Portillo, R., Presbitero, A., and L.F. Zanna, 2015, "Some Misconceptions about Public Investment Efficiency and Growth." IMF Working Paper, No. 15/272.

Biller, D. and I. Nabi, 2013, "Investing in Infrastructure: Harnessing Its Potential for Growth in Sri Lanka."

Briceño-Garmendia, C., Estache, A., and N. Shafik, 2004, "Infrastructure Services in Developing Countries: Access, Quality, Costs, and Policy Reform." World Bank Policy Research Paper No. 3468.

Buffie, E., Berg, A., Pattillo, C., Portillo, R., and L.F. Zanna, 2012, "Public Investment, Growth and Debt Sustainability: Putting Together the Pieces." IMF Working Paper 12/144.

Calderón, C., Easterly, W., and L. Servén, 2003, "Infrastructure Compression and Public Sector Solvency in Latin America." Stanford University Press and the World Bank, 119-38.

Calderón, C. and L. Servén, 2010, "Infrastructure in Latin America." World Bank Policy Research Working Paper No. 5317.

Canning, D. and E. Bennathan, 1999, "The Social Rate of Return on Infrastructure Investments." World Bank Policy Research Working Paper.

Canning, D. and P. Pedroni, 2008, "Infrastructure, Long-Run Economic Growth and Causality Tests for Cointegrated Panels." Manchester School 76 (5): 50427.

Central Bank of Sri Lanka, 2012, "Economic and Social Infrastructure." Chapter 3 of Annual Report 2012.

Dapice, D. and N.X. Thanh, 2009, "Vietnam's Infrastructure Constraints." UNDP, Harvard Policy Dialogue Paper.

De Haan, J., W. Romp, and J.E. Sturm, 2007, "Public Capital and Economic Growth: Key Issues for Europe," in G. Schwartz, A. Corbacho, and K. Funke, eds., Public Investment and Public-Private Partnerships: Addressing Infrastructure Challenges and Managing Fiscal Risks, Palgrave Macmillan UK, pp. 11-20

Estache, A., Speciale, B., and D. Veredas., 2006, "How Much Does Infrastructure Matter to Growth in SubSaharan Africa?"

Foster, V. and C. Briceño-Garmendia, 2010, Africa's Infrastructure: A Time for Transformation, Agence Francaise de Developpement and the World Bank.

Gupta, S., Kangur, A., Papageorgiou, C., and A. Wane, 2011, "Efficiency-Adjusted Public Capital and Growth." IMF Working Paper 11/217.

Hulten, C., 1996, "Infrastructure Capital and Economic Growth: How Well You Use It May Be More Important Than How Much You Have." NBER Working Paper, No. 5847.

CInternational Monetary Fund. Not for Redistribution 
International Monetary Fund, 2004, "Public Investment and Fiscal Policy." International Monetary Fund, Washington, DC.

International Monetary Fund, 2005, "Public Investment and Fiscal PolicyLessons from the Pilot Country Studies." International Monetary Fund, Washington, DC.

International Monetary Fund, 2009, "The Funds Facilities and Financing Framework for Low-Income Countries," $\mathrm{SM} / 09 / 55, \mathrm{SM} / 09 / 55$ Supplement 1, SM/09/55 Supplement2. International Monetary Fund, Washington, DC.

International Monetary Fund, 2015, "Making Public Investment More Efficient." The Fiscal Affairs Department Staff Report.

International Monetary Fund, 2015, "When Public Debt Should Be Reduced." Staff Discussion Note (SDN/15/10). International Monetary Fund, Washington, DC.

International Monetary Fund, 2016, "Macroeconomic Management When Policy Space Is Constrained: A Comprehensive, Consistent, and Coordinated Approach to Economic Policy." Staff Discussion Note (SDN/16/09). International Monetary Fund, Washington, DC.

Kaldor, N., 1961, "Capital Accumulation and Economic Growth," in F.A. Lutz and D.C. Hague, eds., The Theory of Capital, St. Martins Press, 1961, pp. 177-222.

King, R., Plosser, C., and S. Rebelo, 1988, "Production, Growth and Business Cycles." Journal of Monetary Economics 21, pp. 195-232, North-Holland.

Melina, G., Yang, S., and L.F. Zanna, 2016, "Debt Sustainability, Public Investment, and Natural Resources in Developing Countries: The DIGNAR Model." Economic Modelling 52, pp. 630-649, Elsevier.

Rodrik, D., 2016, "The Return of Public Investment." Available via the Internet: https://www.projectsyndicate.org/commentary/public-infrastructure-investment-sustained-growth-by-dani-rodrik-2016-01

Sánchez-Robles, B., 1998, "The Role of Infrastructure in Development: Some Macroeconomic Considerations." International Journal of Transport Economics.

Spence, M., 2015, "Why Public Investment?" Available via the Internet: https://www.projectsyndicate.org/commentary/public-investment-economic-growth-by-michael-spence-2015-02?barrier=true

Sturm, J.E., De Haan, J., and G. Kuper, 1998, "Modelling Government Investment and Economic Growth: A Review and Some New Evidence," in H. Shibata et al., eds., The Welfare State, Public Investment, and Growth, Springer-Verlag.

Sum, M., 2008, "Infrastructure Development in Cambodia." Cambodian Institute for Cooperation and Peace.

Tanzi, V. and H. Davoodi, 2000, "Corruption, Growth, and Public Finances." IMF Working Paper 00/182.

Van Arkadie, B., Huong, P., Hanh, T., Oanh, K., Khoi, D., Thang, D., and J. London, 2010, "Joint Country Analysis: Development Challenges in a Middle-income Vietnam." United Nations, Hanoi.

Warner, A., 2014, "Public Investment as an Engine of Growth." IMF Working Paper 14/148.

Yoshino, Y., 2008. "Domestic Constraints, Firm Characteristics, and Geographical Diversification of Firm-level Manufacturing Exports in Africa." World Bank Policy Research Working Paper Series 4575. 


\section{Appendix}

\section{A. Additional figures and tables}

Figure A.1: Public investment (2011 PPP\$-adjusted, \% of GDP)

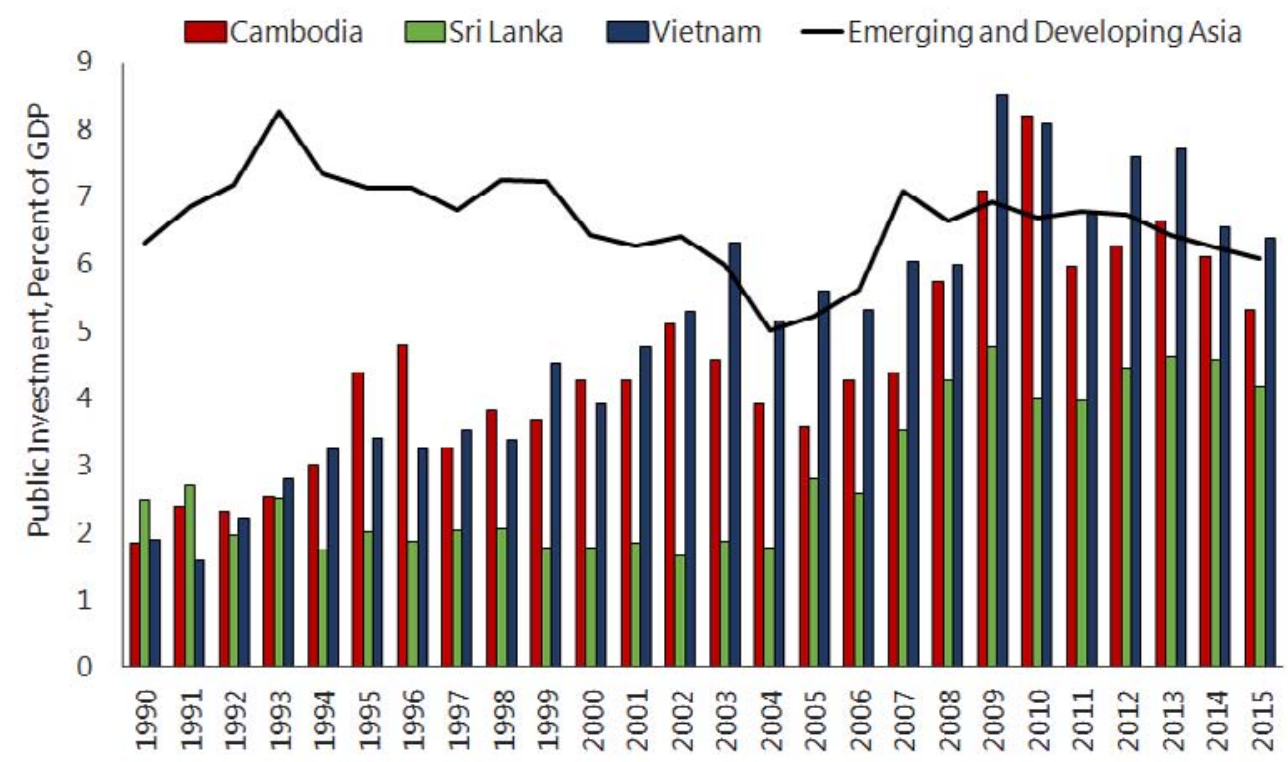

Figure A.2: Private investment (2011 PPP\$-adjusted, \% of GDP)

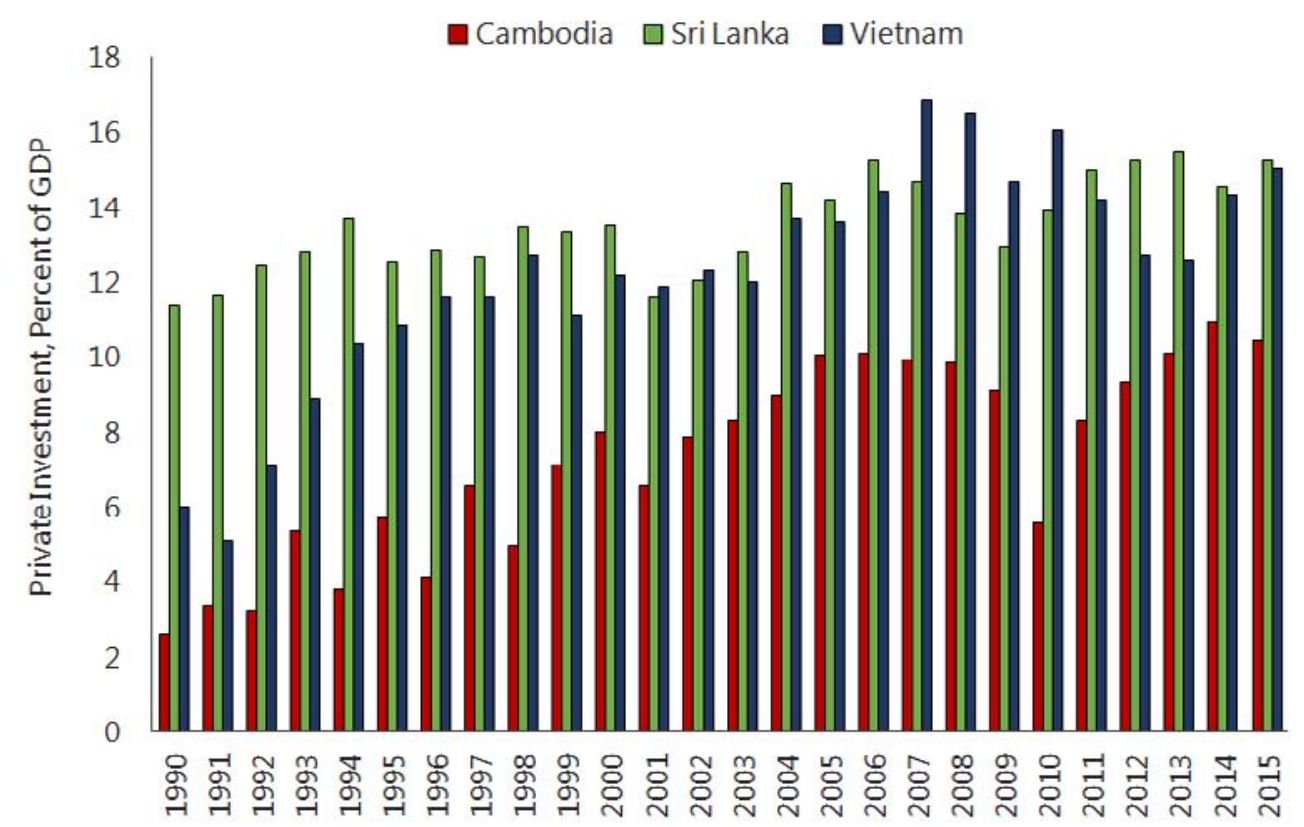

Source: IMF Fiscal Affairs Department. 
Figure A.3: Public capital stock (2011 PPP\$-adjusted, \% of GDP)

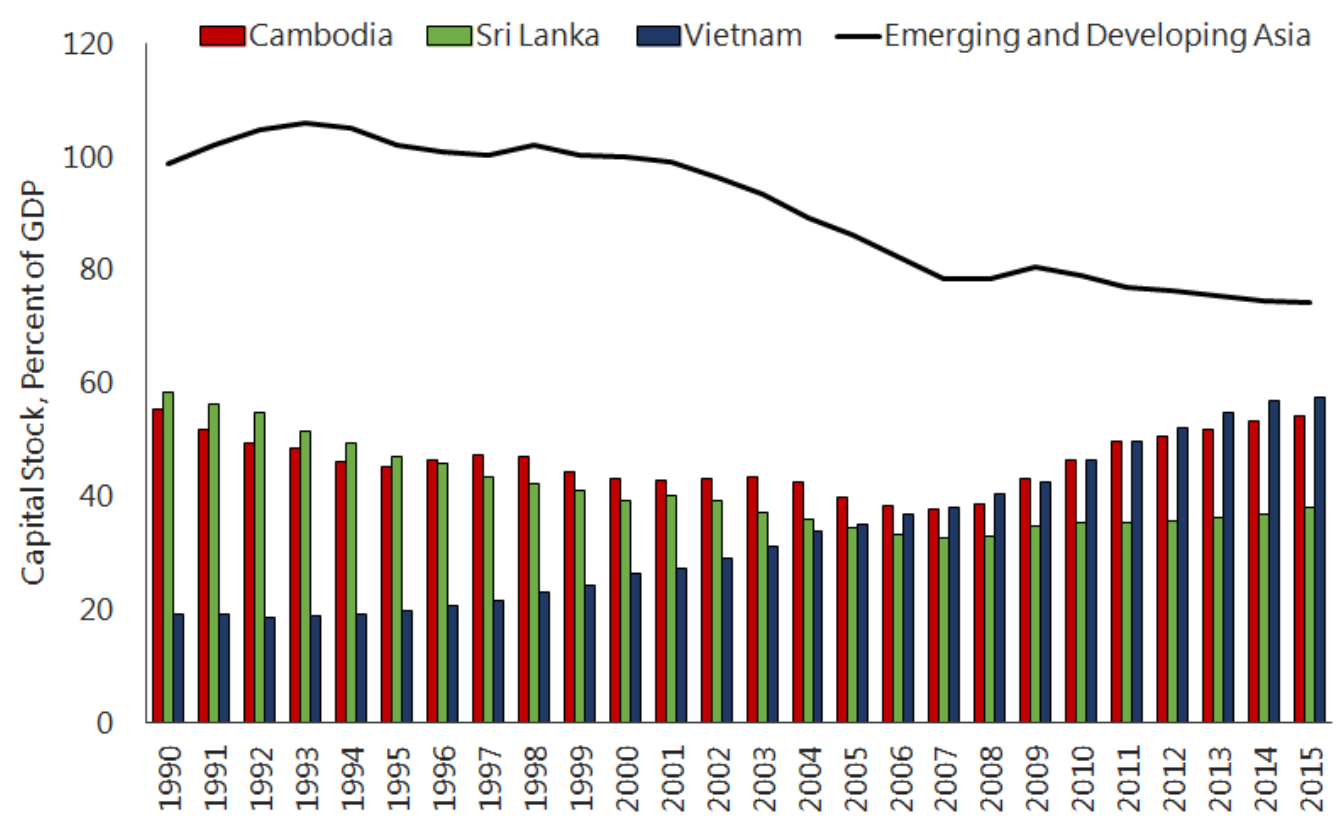

Source: IMF Fiscal Affairs Department.

Note: Calculations using perpetuity growth method with 4 percent growth rates for investment for all countries.

Figure A.4: Public investment performance indicators

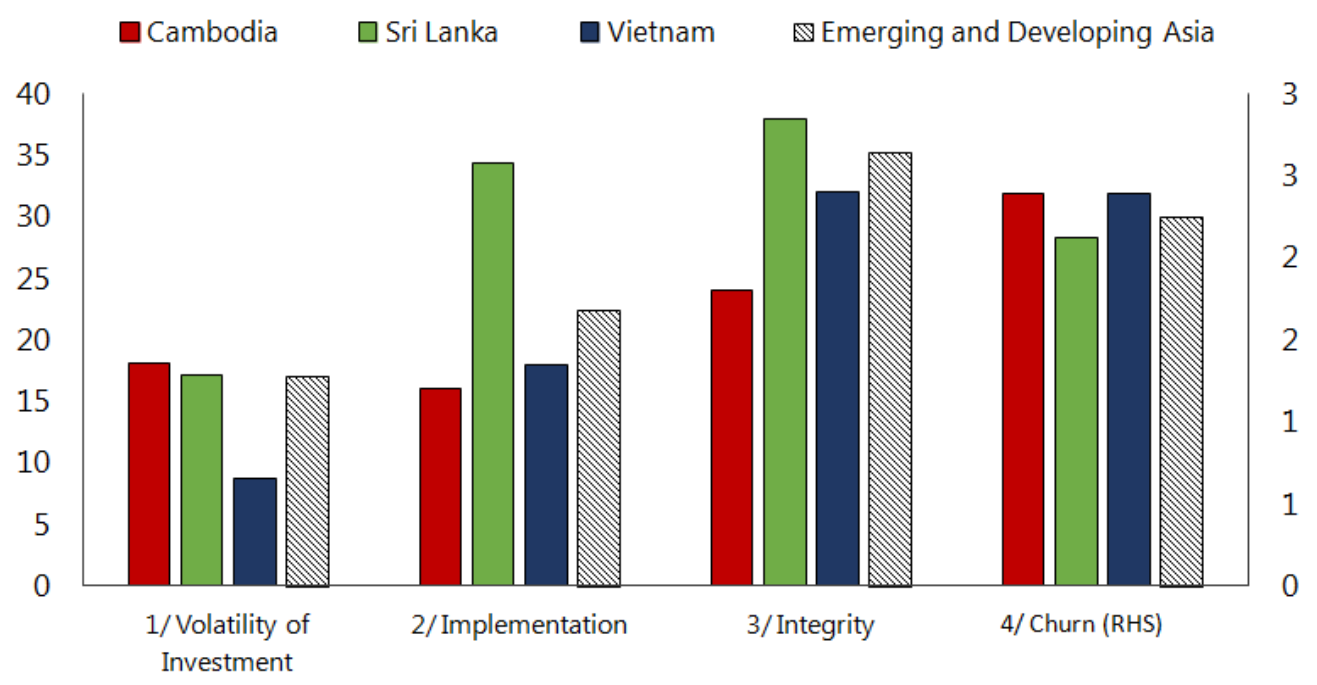

Source: IMF Fiscal Affairs Department.

Notes: 1/ Volatility of Investment is measured by the standard deviation of public investment (percent of GDP); $1990-2013$.

2/ Implementation represents the capacity of capital budget implementation (average absolute percent deviation from planned budget); $2010-2013$.

$3 /$ Integrity is proxied by the 2014 Transparency International Corruption Perception Index. The higher the score, the lower corruption is.

4/ Churn (RHS) is average absolute year-on-year percentage change in the distribution of government investment spending between the nine COFOG nondefense functions of government; available time period varies among countries; 2000-2013. 
Figure A.5: Measures of infrastructure access

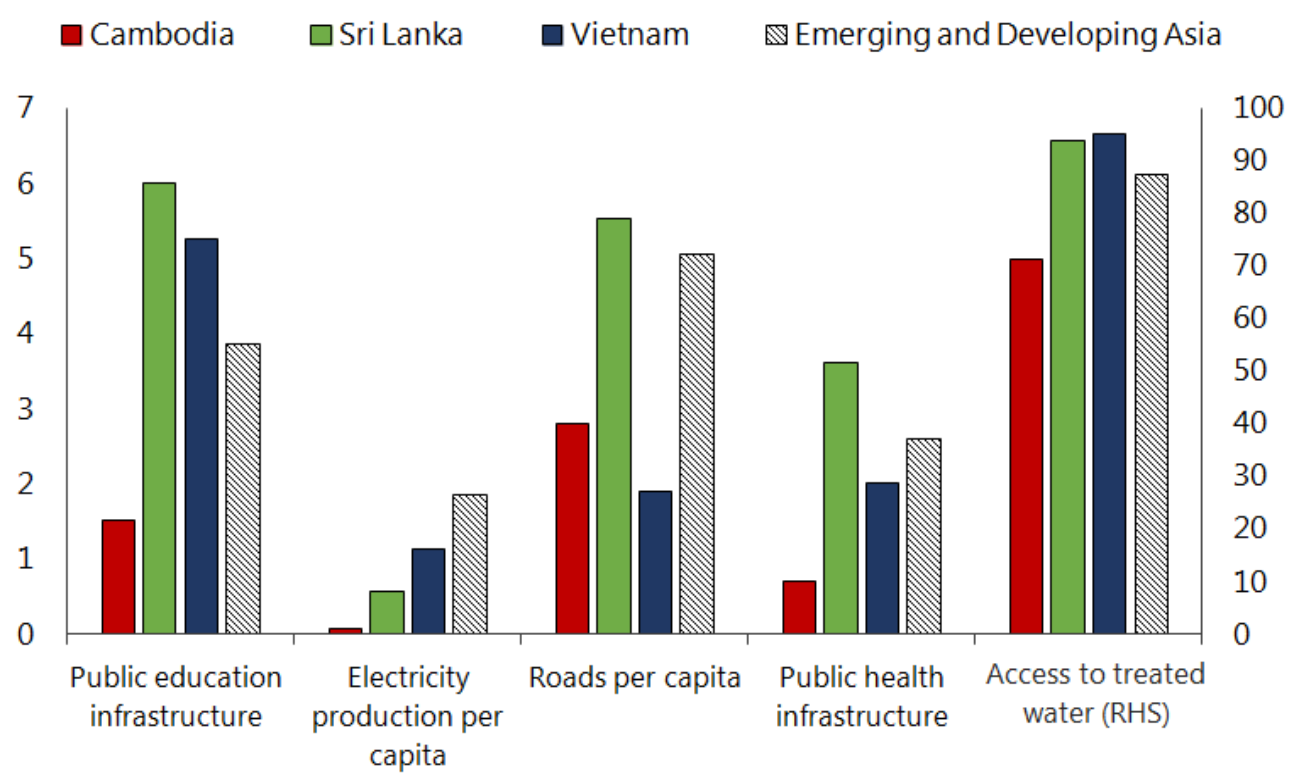

Source: IMF Fiscal Affairs Department.

Note: Most recent year. Units vary to fit scale. Left hand axis: Public education infrastructure is measured as secondary teachers per 1,000 persons; Electricity production per capita as thousands of kWh per person; Roads per capita as km per 1,000 persons; and Public health infrastructure as hospital beds per 1,000 persons. Right hand axis: Access to treated water is measured as percent of population.

Figure A.6: General government revenues (\% of GDP)

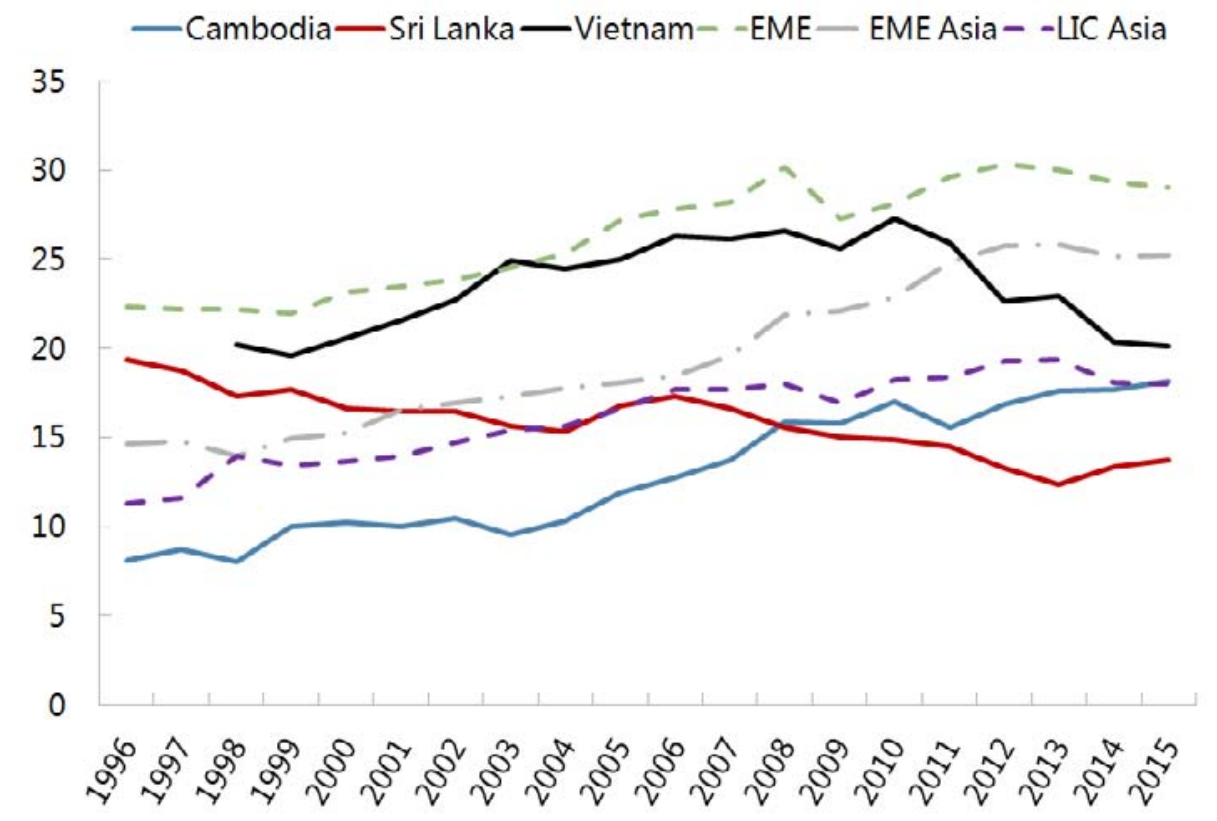

Source: IMF Fiscal Monitor Database. 


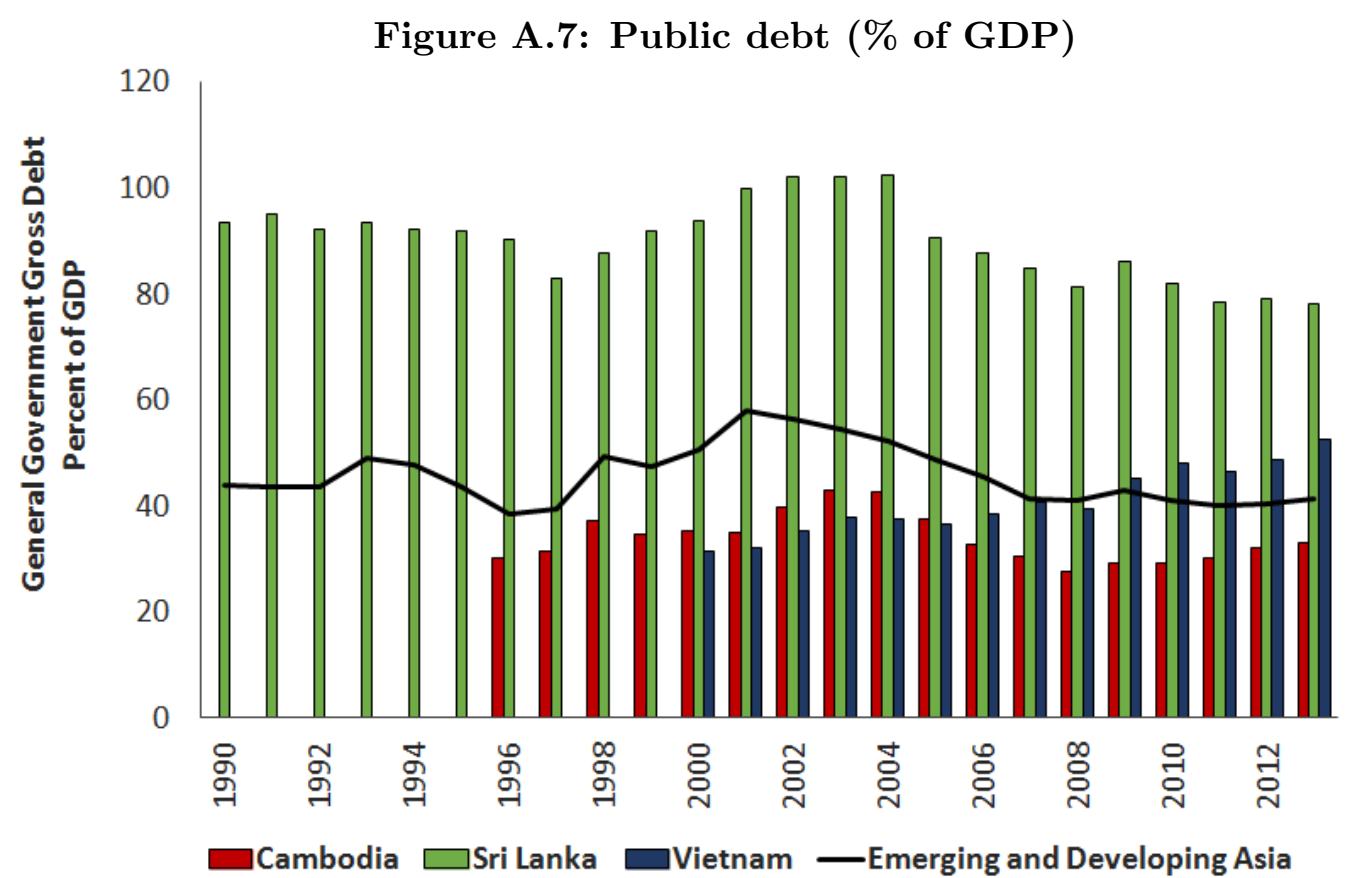

Source: Country authorities and IMF World Economic Outlook. 
Table A.1: Other calibrated parameters

\begin{tabular}{|c|c|c|}
\hline Definition & Param. & Value \\
\hline \multicolumn{3}{|l|}{ Households } \\
\hline Intertemporal elasticity of substitution of consumption & $\varsigma_{c}$ & 0.34 \\
\hline Intertemporal elasticity of substitution of labor supply & $\varsigma_{n}$ & 0.34 \\
\hline Intratemporal elasticity of substitution across consumption goods & $\epsilon$ & 0.50 \\
\hline Portfolio adjustment costs parameter & $\eta$ & 1.0 \\
\hline Depreciation rates $(\%)$ & $\delta_{k}, \delta_{z}$ & 5.0 \\
\hline \multicolumn{3}{|l|}{ Firms } \\
\hline Capital's share in value added in the traded goods sector & $\alpha_{x}$ & 0.55 \\
\hline Capital's share in value added in the nontraded goods sector & $\alpha_{n}$ & 0.40 \\
\hline Cost share of nontraded inputs in the production of private and public capital & $a_{k}, a_{z}$ & 0.50 \\
\hline \multicolumn{3}{|l|}{ Government } \\
\hline Share of tax adjustment through CIT (\%) & $\lambda_{\tau_{p}}$ & 25.0 \\
\hline Share of tax adjustment through PIT (\%) & $\lambda_{\tau_{l}}^{p}$ & 25.0 \\
\hline Taxes reaction to deviations from their target (\%) & $\lambda_{1, \tau_{c}}, \lambda_{1, \tau_{l}}, \lambda_{1, \tau_{p}}$ & 25.0 \\
\hline Tax reaction to debt deviations from its target (\%) & $\lambda_{2, \tau_{c}}, \lambda_{2, \tau_{l}}, \lambda_{2, \tau_{p}}$ & 2.0 \\
\hline User fees fraction of recurrent spending $(\%)$ & $\mu$ & 50.0 \\
\hline Speed of efficiency gains in public investment and tax revenue collection & $\varrho_{s}, \varrho_{\tau}$ & 0.50 \\
\hline Public debt risk premium parameter & $\eta_{g}$ & 1.0 \\
\hline Risk-free world real interest rate & $r^{*}$ & 4.0 \\
\hline
\end{tabular}

Note: Same for the three countries. Additional details on the calibration can be found in Buffie et al. (2012). 